\title{
Who's Going Green and Why? \\ Trends and Determinants of Green Investment
}

\author{
Luc Eyraud, Abdoul Wane, Changchang Zhang, \\ and Benedict Clements
}




\title{
IMF Working Paper
}

Fiscal Affairs Department

\author{
Who's Going Green and Why? Trends and Determinants of Green Investment \\ Prepared by Luc Eyraud, Abdoul Wane, Changchang Zhang, and Benedict Clements ${ }^{1}$
}

December 2011

\begin{abstract}
This Working Paper should not be reported as representing the views of the IMF. The views expressed in this Working Paper are those of the author(s) and do not necessarily represent those of the IMF or IMF policy. Working Papers describe research in progress by the author(s) and are published to elicit comments and to further debate.
\end{abstract}

This paper fills a gap in the macroeconomic literature on renewable sources of energy. It offers a definition of green investment and analyzes the trends and determinants of this investment over the last decade for 35 advanced and emerging countries. We use a new multi-country historical dataset and find that green investment has become a key driver of the energy sector and that its rapid growth is now mostly driven by China. Our econometric results suggest that green investment is boosted by economic growth, a sound financial system conducive to low interest rates, and high fuel prices. We also find that some policy interventions, such as the introduction of carbon pricing schemes, or "feed-in-tariffs," which require use of "green" energy, have a positive and significant impact on green investment. Other interventions, such as biofuel support, do not appear to be associated with higher green investment.

JEL Classification Numbers: Q27, Q40, Q50

Keywords: Renewable resources and conservation, energy, environmental economics

Authors’ E-Mail Addresses: LEyraud@imf.org,AWane@imf.org,BClements@imf.org

\footnotetext{
${ }^{1} \mathrm{We}$ are grateful to Ben Jones for useful discussions during the paper's nascent stage, as well as the comments and suggestions received from Alex Bowen, Benjamin Carton, Derek Eaton, Thomas Helbling, Lusine Lusinyan, Ian Parry, and Fulai Sheng. Jeffrey Pichocki and Alica Dzelilovic provided editorial help. Matias Antonio, Lilla Nemeth, and the team of Bloomberg New Energy and Finance provided data management support.
} 


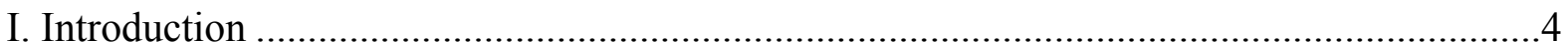

II. What Is Green Investment and How Can It Be Measured? ........................................5

A. Definition and Components of Green Investment ...............................................5

B. Measuring Green Investment ........................................................................

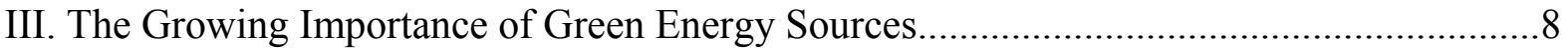

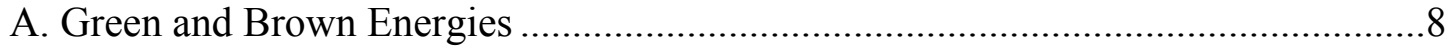

B. Government Support for Renewables ............................................................ 10

IV. What Are the Recent Trends in Green Investment? ...................................................14

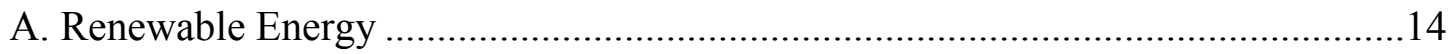

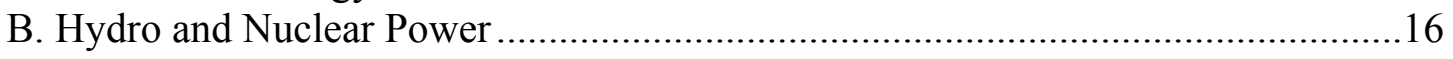

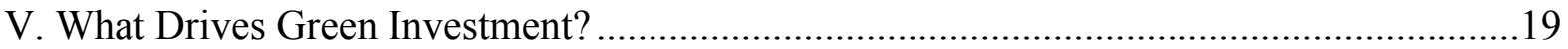

A. Theoretical Determinants of Green Investment ...............................................19

B. Empirical Model and Econometric Results......................................................22

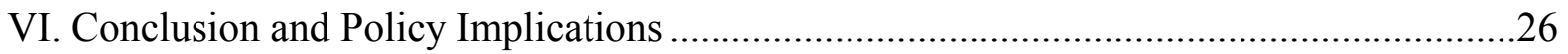

Tables

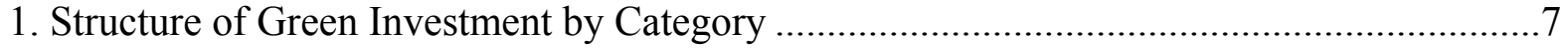

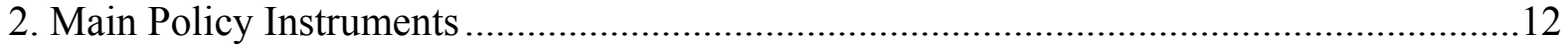

3. Estimates of Public Support for Renewables...............................................................13

4. Green Investment Determinants ........................................................................... 25

Figures

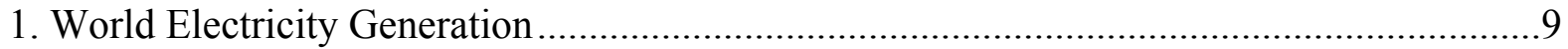

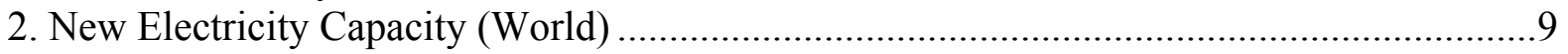

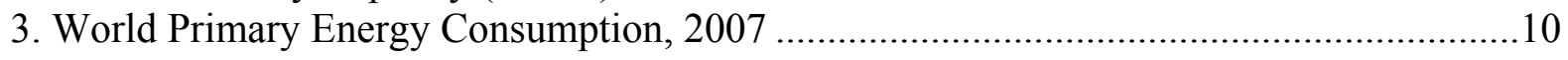

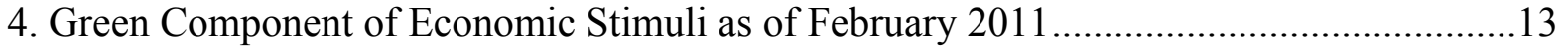

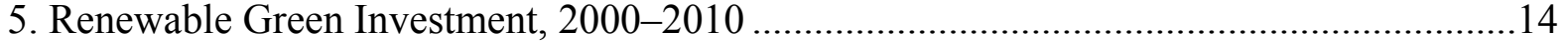

6. Renewable Green Investment by Region, 2004-2010...............................................15

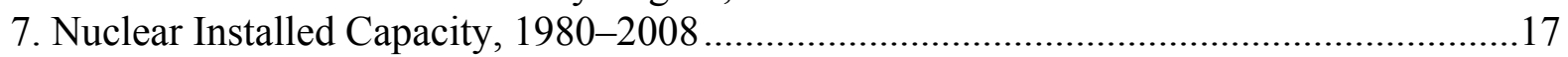

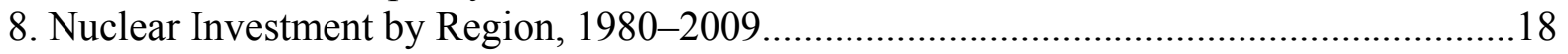

9. Installed Hydroelectric Capacity, 1980-2008 ................................................................ 19

Box

1. Selected Renewable Technologies: Terminology and Key Features................................29

Appendices

1. Green Investment in Economic and Business Publications ........................................27

2. The New Energy and Finance Database ..................................................................28

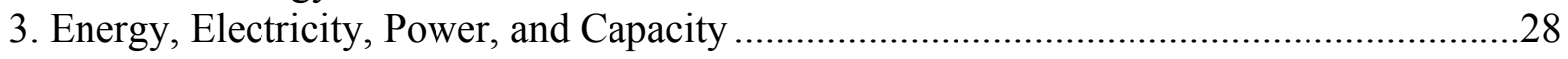

4. Key Renewable Technologies: Definition and Trends ..............................................29 


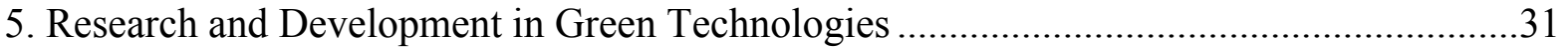

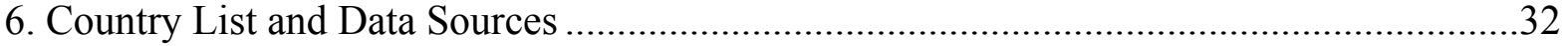

Appendix Table

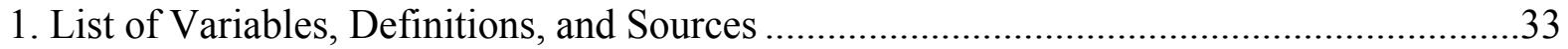

Appendix Figures

1. Renewable Green Investment by Technology, 2004-2010 30

2. Public and Private R\&D in the World

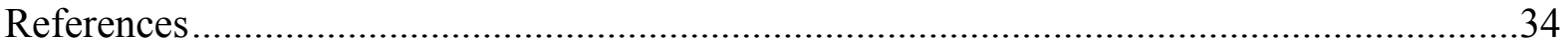




\section{INTRODUCTION}

There is now a wide consensus that climate change is occurring, caused by human-induced greenhouse gas emissions, mainly from fossil fuel combustion and changes in land use. Climate change could produce severe negative outcomes and have important macroeconomic consequences. Higher temperatures, rising sea levels, and extreme weather conditions may severely impair output and productivity (IMF 2008a). Climate developments will also affect fiscal positions through their direct impact on tax bases and spending programs, and more importantly, through the policies needed to mitigate climate change and adapt behaviors and production to the new environment (IMF 2008b, Jones and Keen 2009, Parry 2011). These costs and risks point to the unsustainability of current patterns of energy use. At the same time, the transition to a low-carbon emission model will require large investments in alternative energy sources, because green technologies, such as wind turbines or solar panels, are capital-intensive, especially in the early stages of development (Johnson and Lybecker 2009).

Increasing the share of green investment (GI) is not only a medium-term climate target. Proponents of investment in low-carbon energy sources also cite the need to enhance energy security, reduce adverse health effects of air pollution, and find new sources of growth (PriceWaterhouseCoopers 2008, McKinsey 2009, Accenture 2011, OECD 2011). As of today, GI is already a significant contributor to electricity and energy generation. Renewable energies and nuclear power represent one-third of electricity generation worldwide, and almost one-fourth of total energy consumption (IEA WEO 2010). The pace of green capital accumulation has accelerated in recent years, led by technological progress, economies of scale, strong policy support, and favorable public opinion. Green programs had also proven to be important in national fiscal stimulus plans during the 2008/09 global financial crisis.

The purpose of this paper is to analyze and explain recent trends in GI based on a new multicountry dataset, with a view to better understanding what policies have been successful in promoting it. To our knowledge, no study has yet been conducted that defines the concept of $\mathrm{GI}$ in a macroeconomic sense, and relates it to macro determinants from a cross-country perspective.

The paper utilizes a broad definition of GI, which encompasses both traditional energy sources (e.g., nuclear, hydropower) and new technologies. It shows that GI has become a key driver of the energy sector, as it now exists on a similar scale to investment in fossil-fuel capacity. GI is also a global phenomenon, with leadership shifting from Europe and the United States in the 1990s to China in more recent years.

Our econometric results have important implications for the design of policies to bolster GI. They suggest that macroeconomic policies that are generally effective for increasing private investment as a whole are also useful for GI, in particular, enhancing GDP growth and lowering the cost of capital. At the same time, not all public interventions are successful in 
boosting GI. Feed-in tariffs (a form of price support) and carbon pricing mechanisms are found to foster GI, while other policies, like biofuel support, do not appear to be associated with higher investment rates.

The paper is organized as follows: Section II discusses conceptual and methodological issues related to the definition and measurement of GI. Section III analyzes the relative importance of green and conventional energy sources. Section IV reviews recent trends in GI, drawing from financial data and other relevant sources. Section $V$ analyzes the determinants of GI from both theoretical and empirical perspectives. Finally, Section VI concludes.

\section{What Is Green Investment and How Can It Be Measured?}

\section{A. Definition and Components of Green Investment}

In this study, GI refers to the investment necessary to reduce greenhouse gas and air pollutant emissions, without significantly reducing the production and consumption of non-energy goods. ${ }^{2}$ GI covers both public and private investment. Our approach to GI differs from that of the forward-looking economic literature on mitigation and abatement costs, which measures the incremental investment needed to meet a certain climate target relative to a business-asusual scenario (Appendix 1).

Core strategies for reducing emissions can be classified according to their intermediate objective. Most GI is intended either to reduce the pollution caused by energy generation, or to decrease energy consumption. In addition, GI also covers technologies that sequester carbon, as deforestation and agriculture are important sources of carbon emission. Accordingly, Table 1 identifies three main components of GI:

- Low-emission energy supply. GI involves shifting energy supply from fossil fuels to less polluting alternatives, either for electricity generation (wind, solar, nuclear, hydropower, etc.), or as direct sources of energy (biofuel, for example). The GI concept thus extends not only to emerging environmental technologies such as wind

\footnotetext{
${ }^{2}$ The emission of greenhouse gases (in particular carbon dioxide) and pollutants (such as sulfur dioxide and nitrogen oxide) lead to global warming, smog, and acid rain, and have adverse effects on health. Our analysis focuses on emission reduction to restrict the scope of the GI concept in light of data availability. Other environmental objectives could have been considered, such as reducing the reliance on fossil fuels, avoiding resource depletion, preventing damages to water and soil, reducing waste, and preserving biodiversity. For instance, Eurostat (2009) adopts a broader approach by defining environmental spending as the acquisition of technologies, goods, and services whose main purpose is to limit the degradation and depletion of natural resources.
} 
and solar photovoltaic power, but also to more established technologies, like nuclear and hydropower. ${ }^{3}$

- $\quad$ Energy efficiency. GI also includes technologies that reduce the amount of energy required to provide goods and services. In the electricity sector, there is scope for improving efficiency in power generation (moving from sub- to super-critical coal) ${ }^{4}$ and transmission and distribution (by using more efficient grids and smart grid technologies). ${ }^{5}$ There is also potential for efficiency gains in transport, including through the utilization of more fuel-efficient and hybrid cars, as well as greater use of mass transit. In industrial equipment, efficiency gains can be achieved through energy-saving appliances and improved waste management. In construction, efficiency could be enhanced through improved insulation and cooling systems.

- Carbon sequestration. After fossil fuel combustion, deforestation is the secondlargest contributor to carbon emissions worldwide, accounting for 20 percent of total emissions (Report of the Intergovernmental Panel on Climate Change 2007). Halting ongoing deforestation, reforesting, and sequestering more carbon in soils through new agricultural practices, are therefore crucial to reducing carbon emissions. Deforestation and agriculture may also offer some of the lowest-cost abatement opportunities. However, the main mitigation strategies in these areas rely on labor, rather than physical capital (for example, changes in crop and soil management practices), and available data on GI in this area is limited.

\footnotetext{
${ }^{3}$ To retain a simple distinction between energy from fossil fuels and low-emission alternatives, our GI concept includes investment in nuclear power. Some have argued that nuclear power should be excluded from any green spending concept, due to the radioactive waste it produces. However, we still include it because our definition is based on the impact of GI on gas emissions. Biofuels are also part of GI, despite their debated impact on carbon emissions (IMF 2008d), so that all renewable energy sources are considered "green" in our study. For simplicity's sake, our measure excludes "fossil-fuel switching," for example, the replacement of coal with natural gas, which also contributes to emission reduction.

${ }^{4}$ Supercritical coal-fired plants are highly efficient electricity plants that burn less coal per megawatt-hour produced.

${ }^{5} \mathrm{~A}$ smart grid is a form of electricity network using digital technology.
} 


\section{Table 1. Structure of Green Investment by Category}

\begin{tabular}{|c|c|c|c|c|}
\hline & Component & \multicolumn{3}{|c|}{ Item and Sub-Item } \\
\hline \multirow[t]{2}{*}{$\begin{array}{l}\text { Supply } \\
\text { Factors }\end{array}$} & Low-emission energy supply & \multicolumn{3}{|c|}{ 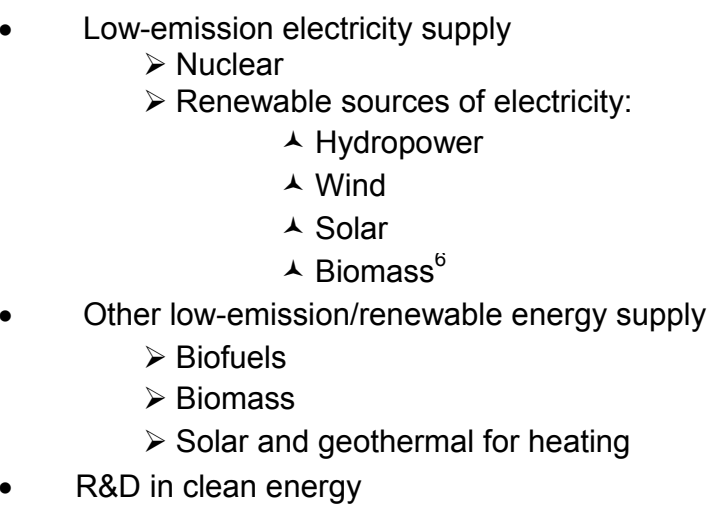 } \\
\hline & Carbon sequestration & $\begin{array}{ll}\text { - } & \text { Agriculture } \\
\text { - } & \text { Deforestatior } \\
\text { - } & \text { Carbon capt }\end{array}$ & & nologies \\
\hline $\begin{array}{l}\text { Demand } \\
\text { Factors }\end{array}$ & $\begin{array}{l}\text { Energy efficiency in energy- } \\
\text { consuming sectors }\end{array}$ & $\begin{array}{ll}\text { - } & \text { Households } \\
\text { - } & \text { Industry } \\
\text { - } & \text { Transport }\end{array}$ & & $\begin{array}{l}\text { Services } \\
\text { Agriculture }\end{array}$ \\
\hline $\begin{array}{l}\text { Mixed } \\
\text { Factors }^{7}\end{array}$ & \multicolumn{4}{|c|}{ Energy efficiency in the electricity sector (generation, transmission, distribution) } \\
\hline
\end{tabular}

\section{B. Measuring Green Investment}

Our measure of GI covers: (i) financial investment in renewable technologies (including large hydroelectric projects), (ii) capacity investment in the nuclear sector, (iii) selected energy-efficient technologies, ${ }^{8}$ and (iv) research and development (R\&D) in green technologies. Investment in carbon sequestration, which is difficult to measure, is excluded from the analysis.

Excluding large hydro projects, data on renewable GI is provided by Bloomberg New Energy Finance (BNEF). BNEF has the most complete database on renewable energy projects and is widely used by public and private entities (Appendix 2). BNEF records financial investment

\footnotetext{
${ }^{6} \mathrm{Biomass}$ is carbon neutral in that plants absorb and store carbon while they are growing and return it when they burn or decay.

${ }^{7}$ The electricity sector both demands and produces energy, making it difficult to categorize efforts to improve energy efficiency in this area into those that affect energy demand or supply.

${ }^{8}$ The Bloomberg New Energy Finance database used in this study only covers selected energy efficient technologies, labeled under the category "Energy Smart Technologies" (for instance, smart grids or power storage).
} 
(acquisition of financial assets), which may differ from physical investment, although project financing is usually earmarked in the renewable sector. Investment covered by the database is mostly private, but BNEF separately reports the green component of fiscal stimulus programs and public R\&D spending.

Where financial data is unavailable, investment is measured from capacity data. ${ }^{9}$ We adopt this approach in the case of nuclear power. Investment in nuclear power is approximated by the change in capacity times an average fixed capital cost of $\$ 4,000 / \mathrm{kW}$ suggested by ex-post studies (Schlissel and Biewald 2008), taking into account an average service life of 40 years for nuclear plants and a geometrical depreciation rate of 2.1 percent (based on estimates from the U.S. Bureau of Economic Analysis). ${ }^{10}$

In the case of hydroelectricity, estimating investment flows from capacity data is particularly challenging. This is because capital costs are likely to be highly heterogeneous, being affected not only by the type of technology and the efficiency of project implementation, but also, more fundamentally by essential physical and geological conditions. As such, no estimate of investment flows is attempted; only changes in capacity are reported in Section IV.B.

\section{The Growing IMPORTANCE OF GREEN ENERGy SOURCES}

\section{A. Green and Brown Energies}

Although this paper will focus mainly on financial investment (in Section IV), this section briefly analyzes energy generation data in order to assess the scale of green energy sources (nuclear and renewables) relative to conventional, or "brown," ones (coal, gas, and oil). This section shows that renewables play an important role in electricity and more generally in energy generation, due to the traditional use of hydropower and biomass. ${ }^{11}$

\section{Electricity generation}

In 2008, about one-third of global electricity was generated from green sources (nuclear and renewables), and two-thirds from conventional sources (Figure 1, left). These shares have been relatively stable over time. However, since the second half of the 1990s, green energy generation has slightly shifted from hydro and nuclear to other renewables (Figure 1, right).

\footnotetext{
${ }^{9}$ Capacity refers to the maximum output of electricity and is usually in the form of kilowatts $(\mathrm{kW})$ and megawatts (MW).

${ }^{10}$ Using a fixed nominal cost has the advantage of producing constant-price estimates, although capital costs are likely to have risen over time.

${ }^{11}$ The terms "electricity," “energy," and "power" are defined in Appendix 3.
} 
Figure 1. World Electricity Generation

(Billions of KWh)
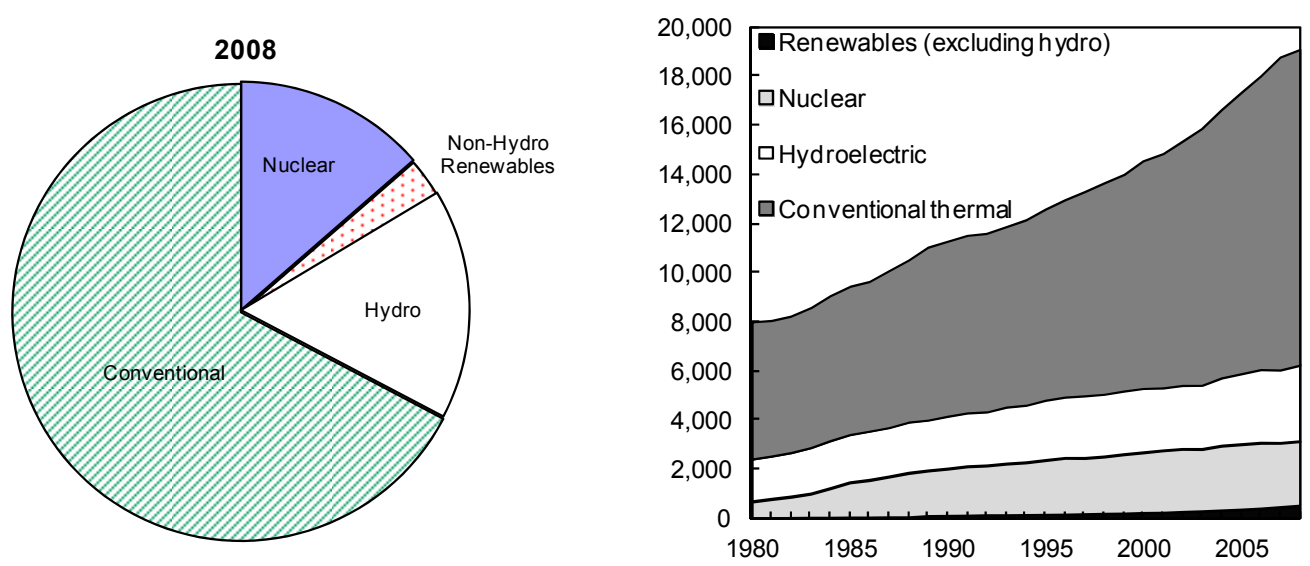

Source: U.S. Energy Information Administration.

Excluding hydroelectric power, renewable technologies account for a small share of the electricity mix compared to traditional resources like fossil fuels, nuclear, or hydropower. However, their contribution to new electricity capacity has been substantial in recent years (Figure 2).

Figure 2. New Electricity Capacity (World)
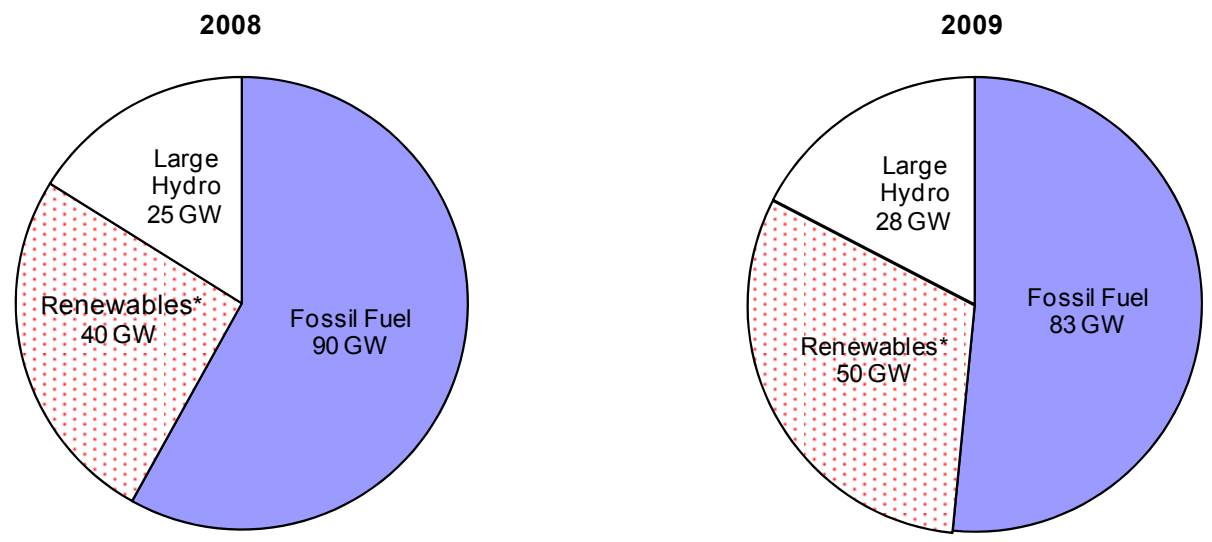

Source: Bloomberg New Energy Finance (BNEF).

${ }^{*}$ Excluding large hydro.

Note: New Nuclear capacity is not reported, as nuclear capacity remained stable in 2008 and 2009.

\section{Energy consumption}

Data on energy consumption is less reliable than that on electricity production because some fuels (like biomass and waste) are non-traded and their consumption is not well documented. 
It should also be noted that there are competing methods of measuring energy. ${ }^{12}$

Depending on the method, green energy sources (renewables and nuclear) supply about 20 to 25 percent of global energy consumption, owing to the traditional role of biomass for cooking and heating (Figure 3, left). Excluding non-traded fuels, the share of renewables and nuclear falls to about 15 percent (Figure 3, right).

\section{Figure 3. World Primary Energy Consumption, 2007}
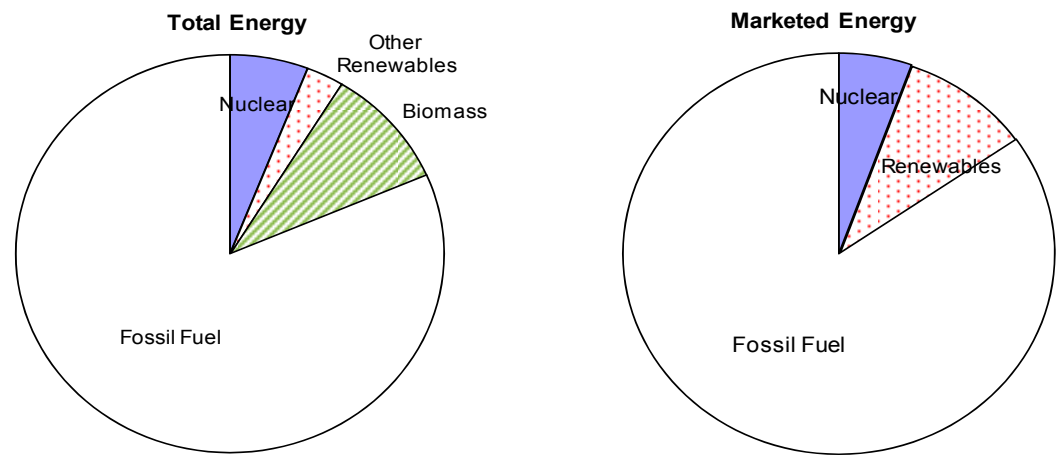

Sources: 2009 World Energy Outlook, 2010 International Energy Outlook.

\section{B. Government Support for Renewables}

Over the last decade, a wide range of public programs have been put in place, mostly in OECD countries, in order to encourage the production or consumption of renewable energy (Table 2). The number of countries with some type of policy target and/or support policy almost doubled during the last five years from 55 in early 2005 to more than 100 by early 2010 (Renewable Energy Policy Network 2010).

Support schemes have three main goals: (i) reduce carbon emissions and avoid climate change, ${ }^{13}$ (ii) improve energy security by diversifying the energy mix; and (iii) foster growth by promoting competitiveness, job creation, and innovation in new industries. ${ }^{14}$

\footnotetext{
${ }^{12}$ Energy can be measured at the point of use (final demand) or at the input stage (primary demand). For instance, the energy produced by an electric plant can be measured by either the electricity generated by, or the fossil fuel needed to, operate the plant.

${ }^{13}$ Achieving this objective faces several obstacles. First, if renewable policies reduce the use of nuclear energy or natural gas rather than coal or oil, the impact on emission is likely to be limited. Second, renewable subsidies are usually seen as less effective than emission pricing (like a carbon tax), because they do not curb energy use and do not deter the consumption of energy-intensive products. They also fail to penalize or reward fuels based on their carbon content, but instead create incentives to use a particular category of fuel (Krupnick and others 2010). Third, the impact on emissions may also be constrained by the existence of cap-and-trade (such as the EU emission trading scheme); any gain in a particular country is likely to be offset by higher emissions in another country covered by the cap.
} 
The most common forms of policy support for renewable electricity generation are feed-intariffs (FITs, adopted by 50 countries and 25 states/provinces by early 2010), and renewable portfolio standards (RPS, found in 10 countries and 46 state/provinces). These terms are described in Table 2. In the case of biofuels, blending mandates are the most widespread instrument-24 countries, 41 states/provinces (Renewable Energy Policy Network 2010).

Estimating the cost of public programs is tricky, as they not only include direct payments but also tax breaks, loan guarantees, or quotas. Published estimates provide a range of $\$ 40-60$ billion per year worldwide (Table 3). Biofuel subsidies account for the lion's share of public program costs. Although total subsidies to renewables only amount to one-tenth of those to fossil fuels, renewables are, in fact, far more subsidized on an output basis (relative to the energy produced). ${ }^{15}$

Several of these programs have been scaled up in the context of the fiscal policy response to the 2008/09 global financial crisis. The Renewable Energy Policy Network (2010) and BNEF (2011a) estimate that support of clean energy, pledged as part of fiscal stimulus plans, amounts to about $\$ 180-195$ billion, of which the United States, China, and South Korea account for around $\$ 65, \$ 46$, and $\$ 32$ billion, respectively. In the countries with the largest green packages (Figure 4), green measures represent no more than 15 percent of the total fiscal stimulus, ${ }^{16}$ except for South Korea, where 80 percent of the stimulus was earmarked for green investment.

The largest share of the green stimulus financing (almost one-fourth) went to energy efficiency measures, in the form of grants for the improvement of public sector buildings and for weatherizing homes (BNEF 2010c). Only half of the total allocated funds were disbursed in 2009 and 2010 ( $\$ 20$ and $\$ 74$ billion, respectively). Implementation of green stimulus financing has been slowed down by the complex planning and processing required for releasing public financing. In addition, countries facing large public sector deficits have scaled down green spending when the economy started recovering. For instance, some projects appear to have been abandoned in Brazil, China, Spain, and the United Kingdom (BNEF, 2011a).

\footnotetext{
${ }^{14}$ The potential for green job creation should not be overestimated and has been subject to heated debate (see Morriss and others 2009, Tuerck and others 2009, and Pollin 2009).

${ }^{15}$ Measuring subsidies per energy unit, Global Subsidies Initiative (2010a) finds that renewables receive about six times more subsidies than fossil fuels (respectively, $\$ 0.05$ per $\mathrm{kWh}$ compared to $\$ 0.008$ ).

${ }^{16}$ Fiscal stimulus estimates are provided by the IMF Fiscal Monitor (2010).
} 
Table 2. Main Policy Instruments

\begin{tabular}{|c|c|c|}
\hline & Instrument & Description \\
\hline \multirow{3}{*}{$\begin{array}{l}\text { Subsidies to } \\
\text { Producers and } \\
\text { Consumers }\end{array}$} & Direct payments & $\begin{array}{l}\text { Cash transfers and "premia" for green } \\
\text { energy production }{ }^{17}\end{array}$ \\
\hline & Tax breaks & Reduction in tax liabilities \\
\hline & Preferential financing & $\begin{array}{c}\text { Either loan at lower interest rate or } \\
\text { guarantees }\end{array}$ \\
\hline \multirow[t]{3}{*}{ Regulations } & Blending mandates & $\begin{array}{l}\text { Requires that fuels contain a given share of } \\
\text { ethanol with gasoline, or biodiesel with } \\
\text { diesel fuel }\end{array}$ \\
\hline & Feed-in-tariffs $^{18}$ & $\begin{array}{l}\text { Mandate making it compulsory for utilities to } \\
\text { pay prices to green electricity producers that } \\
\text { reflect the cost of the technology }\end{array}$ \\
\hline & $\begin{array}{l}\text { Cap and trade: } \\
\text { renewable portfolio } \\
\text { standards (RPS) and } \\
\text { green certificates }\end{array}$ & $\begin{array}{l}\text { RPS requires electricity companies to use a } \\
\text { fraction of renewables for their energy } \\
\text { sources. Companies can comply with RPS } \\
\text { requirements by buying certificates from } \\
\text { green producers }\end{array}$ \\
\hline \multirow[t]{4}{*}{ Indirect Support } & $\begin{array}{l}\text { Support for energy } \\
\text { efficiency }\end{array}$ & $\begin{array}{l}\text { A variety of forms; for instance tax breaks to } \\
\text { support efficient lighting and building } \\
\text { technologies }\end{array}$ \\
\hline & $\begin{array}{l}\text { Fossil fuel taxation and } \\
\text { cap-and-trade systems }\end{array}$ & Increase the cost of carbon emissions \\
\hline & Upstream support & To intermediate consumption producers \\
\hline & R\&D & $\begin{array}{l}\text { Development and deployment of new } \\
\text { technologies }\end{array}$ \\
\hline
\end{tabular}

Source: IMF staff.

\footnotetext{
${ }^{17}$ Premia are a form of bonus paid to the producers on top of the electricity price (market-driven or regulated). These are a function of the renewable energy generated.

${ }^{18}$ FITs are not recorded under public subsidies, as the premia paid by utilities to renewable energy producers are not necessarily subsidized by the government.
} 
Table 3. Estimates of Public Support for Renewables (Excluding hydro and nuclear power)

\begin{tabular}{|c|c|c|c|c|}
\hline Source & Coverage & Country & Year & Amount \\
\hline ELI (2009) & $\begin{array}{l}\text { Tax expenditures and } \\
\text { direct payments }\end{array}$ & United States & $2002-2008$ & $\$ 29$ billion over the period \\
\hline GSI (2010a) & N/A & World & 2007 & $\begin{array}{c}\$ 47 \text { billion, of which } \$ 27 \text { billion for renewable } \\
\text { sources of electricity; and } \$ 20 \text { billion were for } \\
\text { biofuels. }\end{array}$ \\
\hline $\begin{array}{l}\text { IEA WEO } \\
(2010)\end{array}$ & $\begin{array}{l}\text { FIT, PTC, ITC, GC, } \\
\text { Premiums, mandates }\end{array}$ & World & 2009 & $\begin{array}{l}\$ 57 \text { billion, of which } \$ 37 \text { billion for renewable } \\
\text { electricity source; and } \$ 20 \text { billion were for } \\
\text { biofuels. }\end{array}$ \\
\hline $\begin{array}{l}\text { BNEF } \\
(2010 b)\end{array}$ & $\begin{array}{l}\text { FITs, RECs, tax credits, } \\
\text { cash grants }\end{array}$ & World & 2009 & $\$ 43-\$ 46$ billion \\
\hline
\end{tabular}

Source: IMF staff.

Figure 4. Green Component of Economic Stimuli as of February 2011

(Pledged, not necessarily disbursed; billions of dollars)

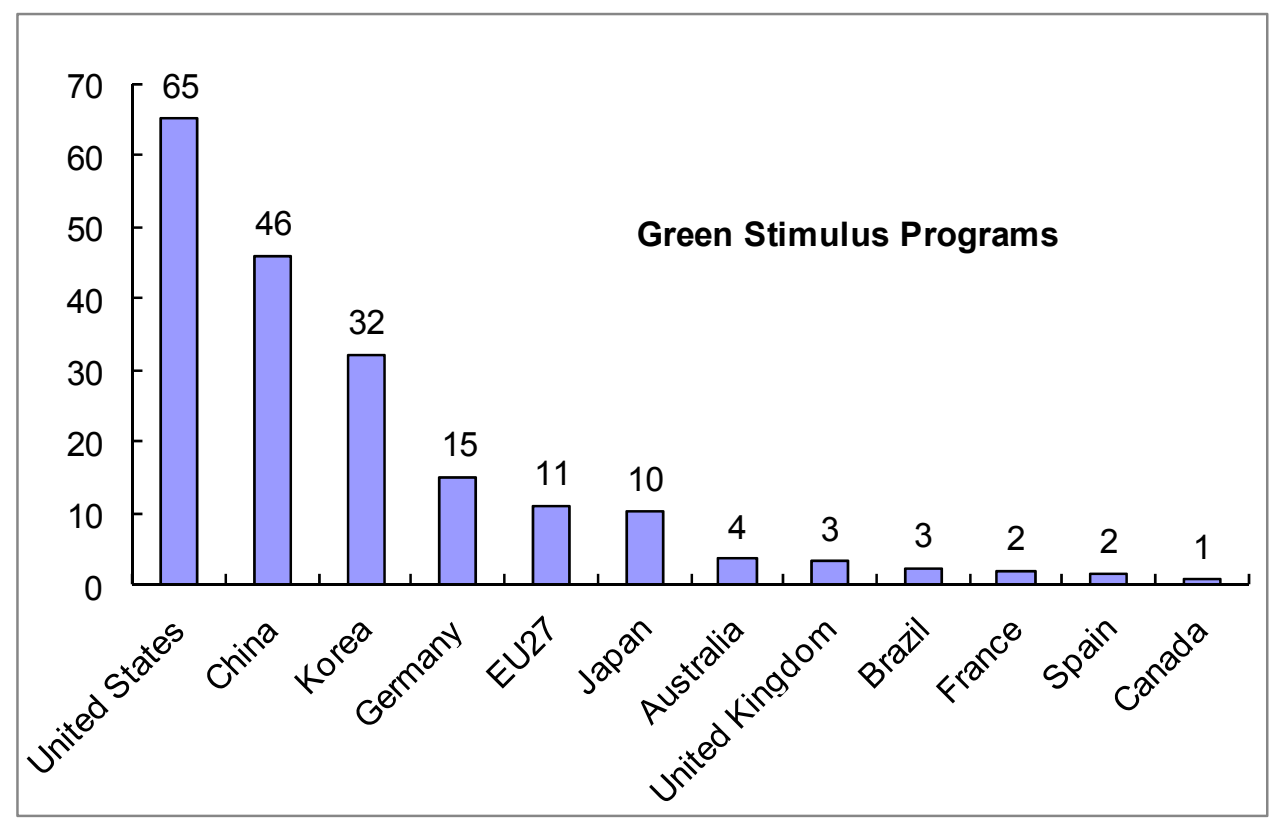

Source: BNEF. 


\section{What Are the ReCENT Trends in Green InVESTMENT?}

\section{A. Renewable Energy ${ }^{19}$}

\section{Global trends}

Renewable GI - as measured by BNEF in current dollars - has risen substantially during the past decade, with most of the increase occurring after 2004. Between 2000 and 2010, renewable GI increased more than twentyfold from $\$ 7$ billion to $\$ 154$ billion (Figure 5). The main drivers include global economic growth, increasing prices of fossil fuels, technology advances, policy support, and increasing demand of populations for a cleaner environment. A reduction in the costs of green technologies has also been realized through economies of scale, technological progress (fostered by R\&D), and lower interest rates. Today, green energy can already compete with fossil fuel sources on an unsubsidized basis in some specific markets (BNEF 2011b), although total renewables remain highly subsidized (Section III.B).

Figure 5. Renewable Green Investment, 2000-2010

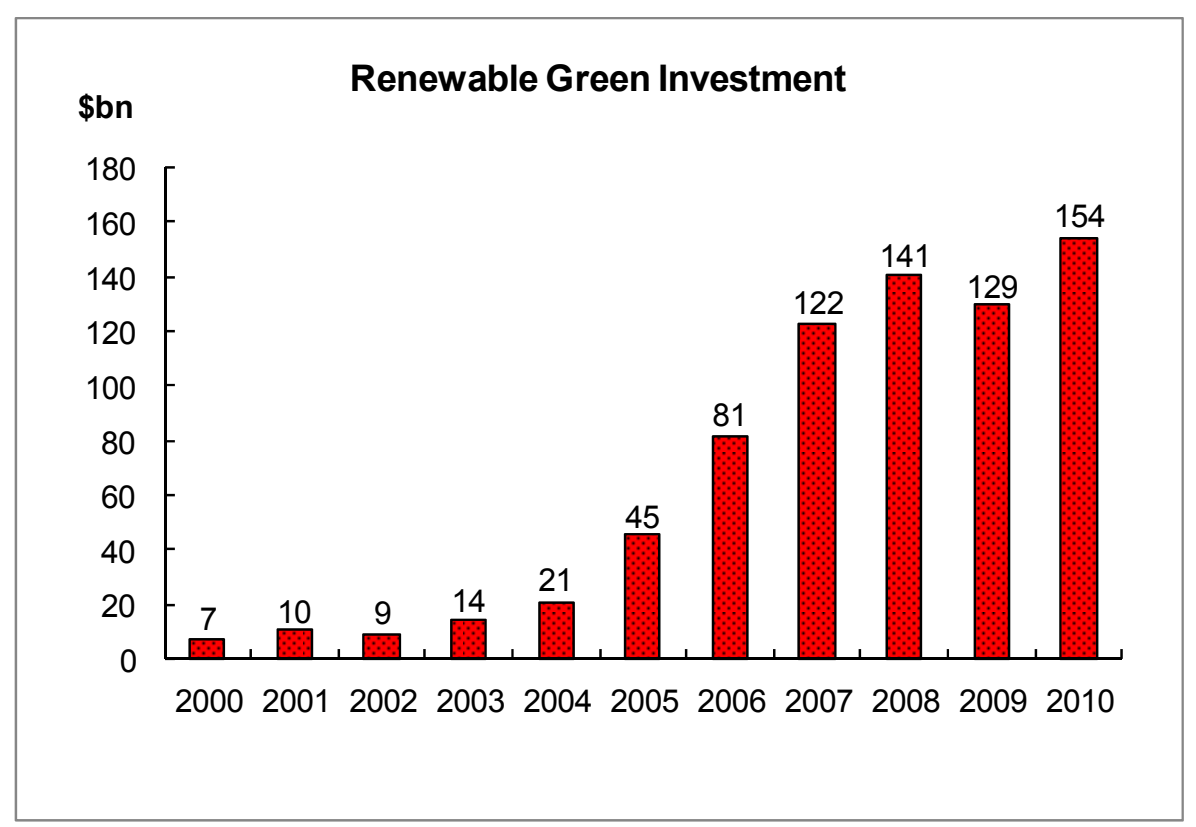

Source: BNEF.

Renewable GI temporarily declined in 2009 during the global recession in the context of less favorable financial conditions, reduced liquidity, and uncertainty over the future demand for green energy as fossil fuel prices receded. This decline was nonetheless countered by the

\footnotetext{
${ }^{19}$ Data used in this section comes from the BNEF database, and excludes large hydro projects (analyzed in Section IV.B). Data is not corrected for inflation, owing to the difficulty in finding a relevant deflator for financial investment. A detailed analysis of the GI components is provided in Appendix 4.
} 
great amount of support received from the public sector: (i) Major development banks (EIB, $\mathrm{KfW}$, EBRD, and WB) stepped in to take over from the private banks to finance large projects in offshore wind and solar thermal, (ii) monetary policy eased globally and interest rates reached historic lows, and (iii) above all, many green projects were supported by public measures in the context of fiscal stimulus programs (see above).

\section{Regional trends}

Renewable GI has become a global phenomenon since the beginning of the last decade (Figure 6). It grew steadily in all major regions until the onset of the economic crisis. From 2004 to 2010, ${ }^{20}$ Europe and North America quadrupled their renewable GIs, while Asia and Oceania increased renewable GIs tenfold. At present, North America, Europe, and Asia are the largest markets for renewable GI, accounting for around \$35 billion, \$36 billion, and $\$ 64$ billion in 2010, respectively. Within Europe, the main investors are Italy, Germany, and Spain, accounting for $\$ 8$ billion, $\$ 7$ billion, and $\$ 5$ billion, respectively. In Asia, China is the leader with $\$ 54$ billion. In North America, the United States invested \$30 billion in 2010 .

\section{Figure 6. Renewable Green Investment by Region, 2004-2010}

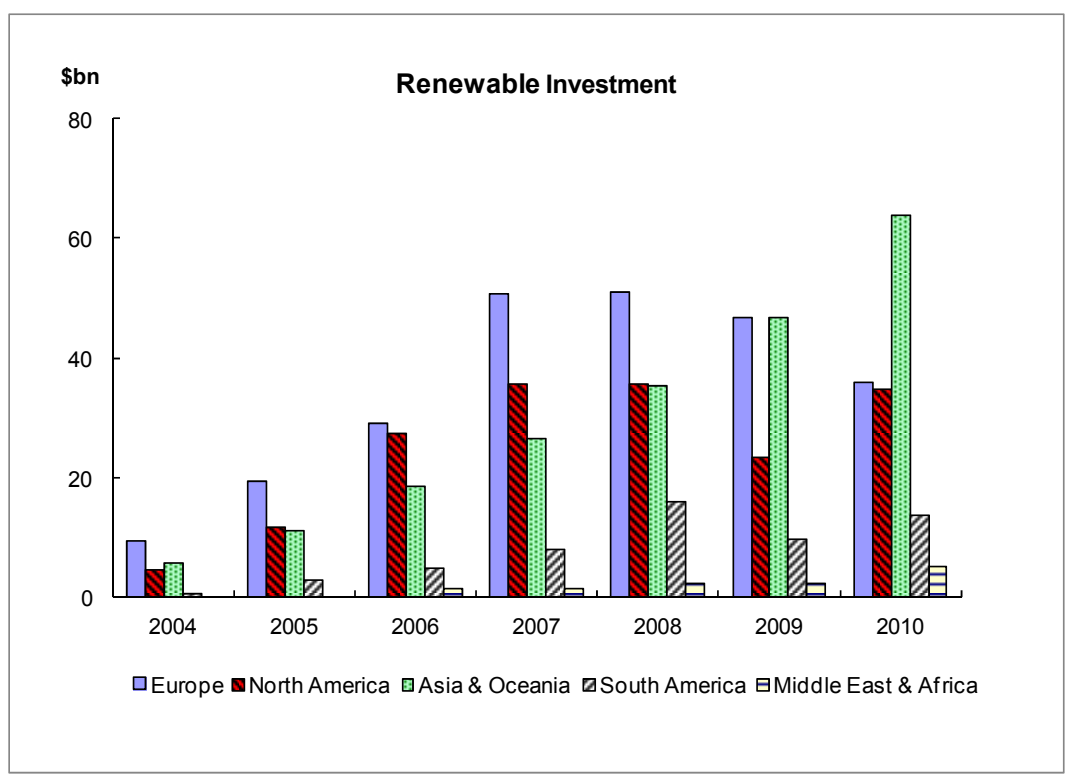

Source: BNEF.

Over the period 2004-2010 the regional composition of GI changed dramatically. Leadership in spending shifted from Europe to Asia, reflecting, to a large extent, differences in economic performance. The share of Europe and North America in global GI fell to 46 percent in 2010, from 68 percent in 2004, while Asia and Oceania's share increased from 28 percent to 42 percent.

\footnotetext{
${ }^{20}$ Investment data on GI components is less reliable (and insignificant) before 2004 in the BNEF database.
} 
In 2009, GI experienced a severe decline in the United States (by $\$ 14$ billion), owing to less aggressive policy support and the effects of the global financial crisis. ${ }^{21}$ This trend was less marked in Europe, where government interventions remained stronger, in particular through feed-in-tariffs (FIT). However, European investment continued to decline in 2010, affected by the lingering credit crunch, whereas investment in the United States picked up.

In contrast, GI in Asia continued to soar during the financial crisis, increasing by about $\$ 30$ billion in 2009 and 2010, with China accounting for the bulk of the growth. This increase was supported by benign macroeconomic conditions, a resilient banking sector, and high saving rates. Through a series of new laws and financial support measures (including loans from state-owned banks), the Chinese government has encouraged large renewable energy projects, with a view to promoting domestic manufacturing industry and improving energy security (U.S.-China Economic and Security Review Commission 2010). In 2009, China moved ahead of the United States as the country with the highest financial investment in renewables, and added $37 \mathrm{GW}$ (gigawatts) of renewable electricity capacity, particularly in wind power, which is more than any other country in the world (Renewable Energy Policy Network 2010). In 2010, China was responsible for more GI than the entire European region alone. It is now the world leader in the production of photovoltaic modules and wind power equipment. China has also stepped up its research and development efforts and has the lead in clean technology patents and Initial Public Offerings (IPOs) in the renewable sector.

\section{B. Hydro and Nuclear Power}

\section{Nuclear investment}

Global nuclear capacity grew rapidly during the 1970s and 1980s, but has been sluggish since the Chernobyl disaster. Global installed capacity grew from $130 \mathrm{GW}$ to $325 \mathrm{GW}$ between 1980 and 1990, and now stands at about 370GW. ${ }^{22}$ As a share of total electrical capacity, nuclear capacity has declined since the early 1990s from about 12 percent in 1990, to 8 percent in 2008 (Figure 7). Even before the recent nuclear disaster in Japan, the industry has confronted a number of obstacles that has stalled its expansion. These include increasing construction costs, a decline in the labor force possessing the necessary specialized skills, insufficient grid capacity, environmental worries, and concerns about safety and nuclear proliferation.

\footnotetext{
${ }^{21}$ In the United States, tax credits offered by the federal government are usually not used by renewable project developers, due to their relatively small size. Instead, they are sold to large institutions called "tax equity investors." These investors put money in green projects in exchange for tax credits, as long as they have taxable profits to shelter. This specific financing mode sustained the development of the renewable sector prior to the financial crisis. Conversely, green investment was badly hit in 2008 and 2009 due to the reduction in the number of tax equity investors (one of the leading providers of tax equity finance was Lehman Brothers), as well as the decline in profits in the wake of the global financial crisis.

22 The term "capacity" is defined in Appendix 3.
} 
Figure 7. Nuclear Installed Capacity, 1980-2008

(GW and as a share of Global Electricity Capacity)

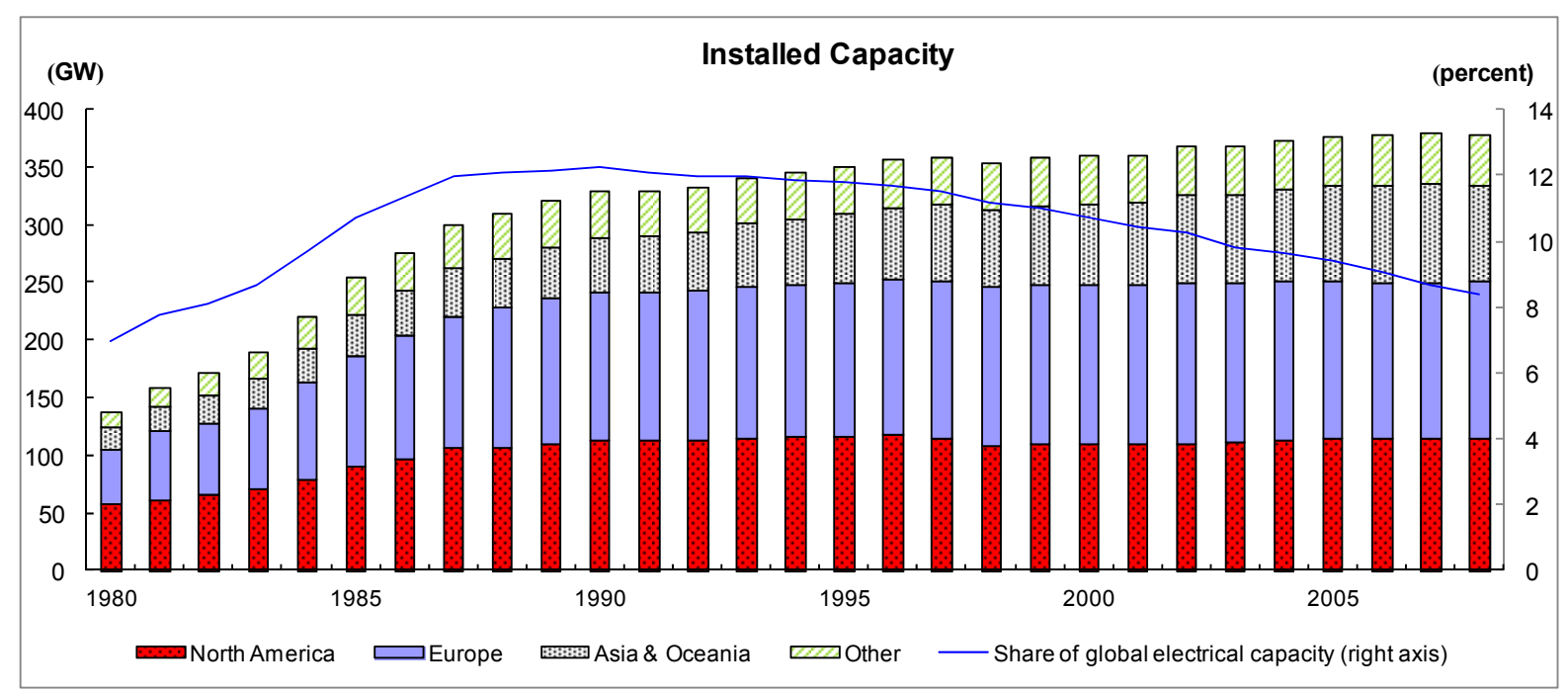

Source: U.S. Energy Information Administration.

Note: "Other" comprises Africa, Eurasia, Middle East, and South America.

Growth is now driven by Asia. Installed capacity in Europe and North America grew on average by 14 percent per year between 1980 and 1990, but these markets have subsequently stalled partly because of public opposition to opening new nuclear sites and building new reactors. In both regions, the number of nuclear reactors under construction decreased from 159 in 1980 to 20 in 2010. By contrast, 42 new reactors are currently under construction in Asia. Asian markets have accounted for about 90 percent of the capacity increase since 1990, and China was the only country with ambitions for nuclear expansion even before the events in Japan (IEA 2010).

Based on capacity data, we computed investment series following the methodology described in Section II.B. In Europe and North America, investment in new capacity (excluding the replacement of depreciated assets) has shrunk in the 1990s and is now negligible (Figure 8, left). On the other hand, investment in Asia averaged $\$ 7$ billion per year during the last decade (with growth shifting from Japan to China). When the replacement of obsolete capital is also taken into account, investment appears to be higher in Europe and North America, because of their larger existing capacity (Figure 8, right).

Government support of the nuclear industry, historically, has been large, including subsidies and contingent guarantees to investment, operating, and waste management, as well as decommissioning costs. ${ }^{23}$ According to Global Subsidies Initiative (2010a), public support to

\footnotetext{
${ }^{23}$ Nuclear decommissioning is the dismantling of a nuclear power plant and decontamination of the site to a state no longer requiring protection from radiation for the public.
} 
the industry amounted to $\$ 45$ billion in 2007 , about the same size as that of renewables (excluding hydropower). ${ }^{24}$

Figure 8. Nuclear Investment by Region, 1980-2009

(Annual average investment; billions of dollars)

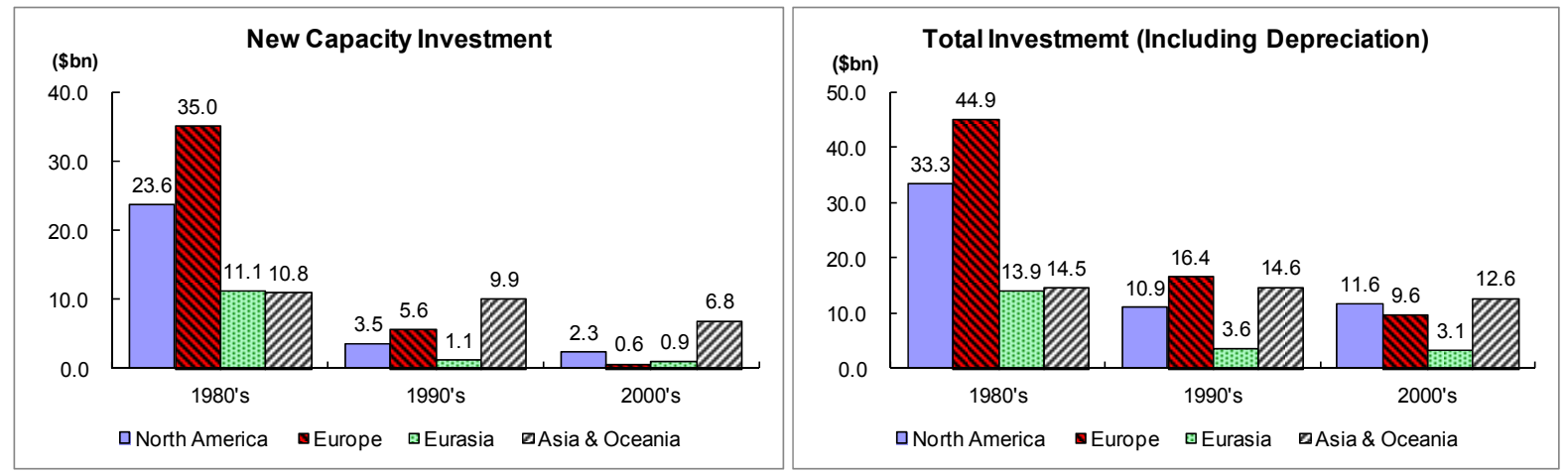

Sources: International Atomic Energy Agency; IMF staff estimates.

\section{Hydropower capacity}

Hydropower is the second-largest renewable energy source (after biomass) and the largest source of renewable-based electricity. Global hydro capacity has grown steadily from $480 \mathrm{GW}$ in the 1980 s to $920 \mathrm{GW}$ in 2007 , aided by the relatively inexpensive construction costs of this energy source vis-à-vis its alternatives. As a share of total electrical capacity, hydropower has, nonetheless, declined from 23 percent in the early 1980s to 19 percent in 2008 (Figure 9). Environmental regulations, and stagnation in technological advances in this area, have slowed down expansion in industrialized countries, and many of the best sites for hydropower have already been exploited. Compared to other renewables and nuclear power, hydro projects do not benefit from significant public support, owing to better cost competitiveness.

Respectively, Asia, Europe, and North America currently account for 32 percent, 30 percent, and 20 percent of total capacity. Over the last decade, capacity growth has been the strongest in Asia, with an average annual growth of 12 percent; compared to about 1.5 percent in Europe or North America. China has been the most dynamic market, nearly doubling its hydropower capacity over 2004-09.

\footnotetext{
${ }^{24}$ This figure seems high compared to our investment estimates, but the two are not fully comparable, as capacity investment does not include operating costs. Another explanation could be that our construction cost assumption $(\$ 4,000$ per $\mathrm{kW})$ is too low. Recent studies suggest that the cost of nuclear plants could have soared to $\$ 8,000$ per $\mathrm{kW}$ in recent years (Schlissel and Biewald 2008).
} 
Figure 9. Installed Hydroelectric Capacity, 1980-2008

(In GW and as a share of Global Electricity Capacity)

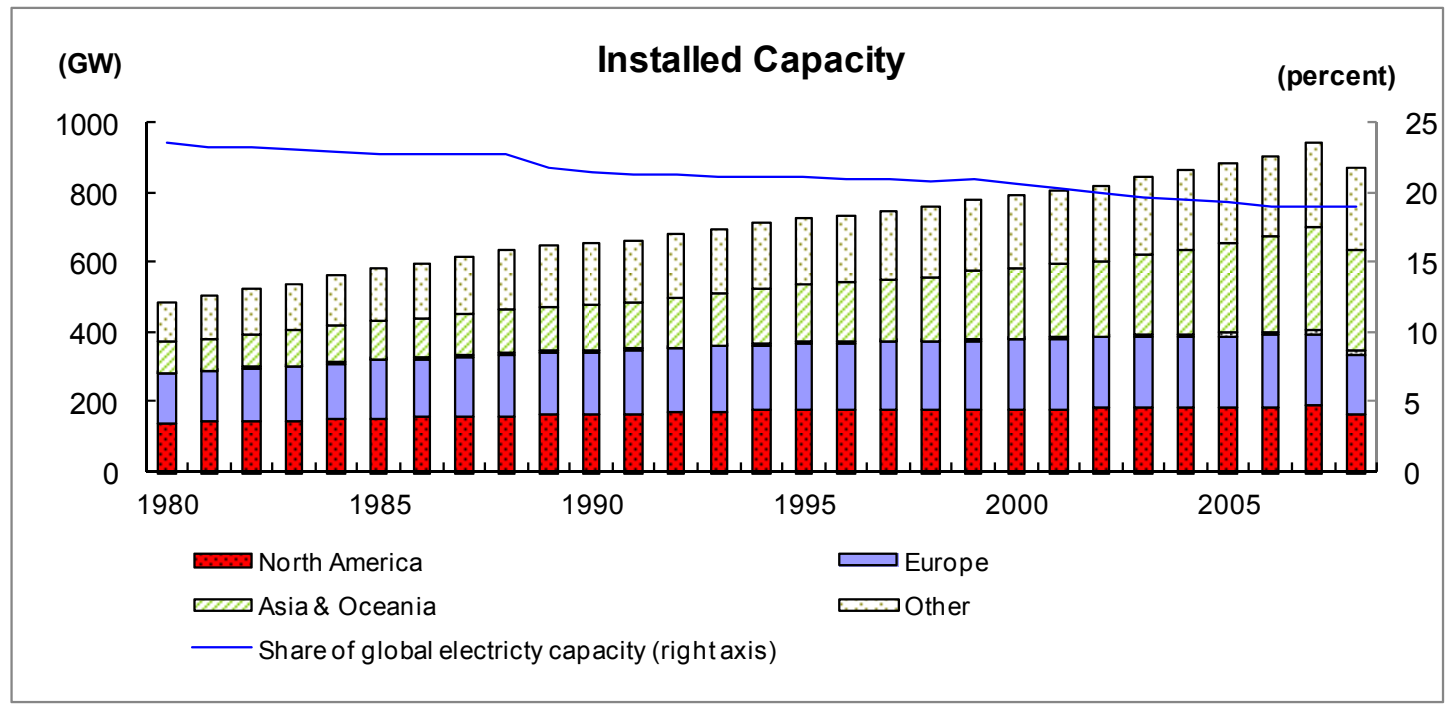

Source: U.S. Energy Information Administration.

Note: "Other" comprises Africa, Eurasia, Middle East, and South America.

\section{WhAT DRIVES GREEN INVESTMENT?}

The economic literature on climate change has largely overlooked the macroeconomic determinants of GI. Most studies have focused on the design of policies to curb greenhouse gas emissions, emphasizing the costs and benefits of limiting environmental damage (Stokey 1998, Sliglitz 1998). Some studies have looked at the determinants of energy-saving innovations at the firm level (Ambec and Lanoine 2007) or at the sector level (Brunnermeier and Cohen 2003). Others have examined the determinants of low-carbon investment at the manufacturing firm level (Martin, Muûls, and Wagner 2011). As far as we know, however, no study has attempted an empirical investigation of the macroeconomic drivers of GI. This section aims at bridging this gap, using data on renewable investment from BNEF on 35 advanced and emerging countries over 2004-2010.

\section{A. Theoretical Determinants of Green Investment}

The economic literature suggests two broad categories of drivers of GI. The first category includes traditional determinants of investment as a whole, for instance, interest rates, income level and growth, and production costs. The second category covers determinants specific to green capital accumulation.

- Economic growth and income level. Economic activity is expected to boost demand for energy and investment in the energy sector ("accelerator effect"). In addition, the "environmental Kuznets curve" (EKC) hypotheses that at higher levels of development, structural change toward information-intensive industries and services, 
international relocation of manufacturing industries, increased environmental awareness, and better enforcement of environmental regulations should result in larger environmental expenditures and a gradual decline of environmental degradation. The theoretical underpinnings of this EKC have been intensively debated (Stern 2004). Nevertheless, several authors have found that while increases in GDP may be associated with worsening environmental conditions in poor countries, economic growth tends to be associated with lower pollution once a critical level of income is reached (Grossman and Krueger 1994, Selden and Song 1994, Cropper and Griffiths 1994, and Stern and others 1996). To capture these relationships, we include GDP growth and level variables in the econometric analysis.

- Population. Population variables could have an impact on GI beyond that of economic growth, as parts of fuel consumption and land use do not pass through formal markets, especially in developing countries (for instance, consumption of fuel woods). Countries with rapidly increasing populations face important energy needs, which are not always well reflected by GDP growth. These needs require investment in alternative energy sources, especially when fossil fuels are scarce or relatively expensive, and/or when renewable resources are abundant (like water in China). In addition, countries may encourage investment in green technologies to offset increases in gas emissions unrelated to production. We expect a positive relationship between population and GI, as is found in other, more general, equations for investment (e.g., Baldacci and others 2007).

- Technological progress and innovation. The expansion of GI has also been made possible by innovation. For instance, new techniques to store energy have fostered the use of intermittent energy sources, like solar or wind power. More generally, the "digital divide" literature shows that investment in new technologies is highly dependent on technical advances and the level of human capital (Guerrieri and others 2010). Skilled workers are more capable of learning how to use new technologies and are more flexible with respect to their job assignments. We expect GI to be positively related to R\&D spending and human capital variables.

- $\quad$ Interest rates. High interest rates reflect the relative scarcity of financing and tend to reduce investment. Renewables should be particularly sensitive to interest rates because the bulk of the cost of producing renewable energy is upfront, and because their capital intensity is generally high compared to traditional technologies. We expect a negative relationship between interest rates and GI.

- $\quad$ The cost of fossil energy sources. High fossil energy prices are expected to foster GI, not only because our GI indicator encompasses investment in the biofuel industry, but also because higher fuel prices lower the cost of the electricity produced from renewables and nuclear power relative to that generated through fossil fuel combustion. This effect is reinforced when carbon emissions are taxed. Newell, 
Jaffee, and Stavins (1999) show that oil price hikes boosted innovations in green technologies that made air conditioners more energy efficient. Popp (2002) provides evidence of the impact of energy prices on patents for energy-saving innovations. In the econometric estimation, we use the international prices of crude oil and coal, and the domestic price of gasoline, to measure the cost of brown capital. In addition, we test the effect of energy dependence (share of imported energy), and of carbon emissions. More polluted or energy-dependent countries may face stronger incentives to invest in green technologies.

- $\quad$ The production cost of green capital goods. The demand for investment should be inversely related to its cost. We include several cost variables in the equation, such as unit labor costs, wages, cost of starting a business, and corporate income tax.

- Profit. If agents have static expectations, the current profit ("cash flow") will be the best predictor of future profits ("profitability"), and as such, will become a determinant of investment. In addition, both variables are related when firms are credit-constrained and have to retain cash flows for investing, or if the access to credit is conditioned by the firm's financial situation (Lamont 1997, Blanchard 2008).

- $\quad$ Public policies to support green investment. Public interventions are necessary to correct market failures stemming from carbon emission externalities. We construct four (time-varying) dummy variables, measuring whether country $i$ in year $t$ implements one of the four main policy instruments: feed-in-tariffs, renewable portfolio standards, biofuel mandates, ${ }^{25}$ and carbon pricing schemes ${ }^{26}$ (described in Section III.B). As these policies are more likely to be conducted by governments sensitive to environmental issues, we also search for a potential relationship between GI and green parties.

- Geophysical conditions. GI should also depend on the availability of natural resources, such as the number of hours of sunshine in a year, or the water and wind supply available. The impact of these variables cannot be assessed in the next section owing to data and econometric constraints (most of these variables being time invariant).

\footnotetext{
${ }^{25}$ Although the share of biofuels in GI has considerably decreased in recent years, it was a major component of GI during the last decade (Appendix 4). In addition, biofuel mandates constitute a very widespread policy (REN21 2010).

${ }^{26}$ The carbon pricing proxy is a time-varying categorical variable taking the value 0 if the country has neither a carbon tax nor a cap-and-trade system in year $t, 1$ if the country has one of the two schemes, and 2 if the country has both.
} 


\section{B. Empirical Model and Econometric Results}

A panel approach is used to identify the determinants of GI and estimate their effect. In this section, GI is measured as financial investment in renewables (using the BNEF database). The panel includes 35 countries over 2000-2010. The following model is estimated in real terms,${ }^{27}$ using the fixed-effect methodology, ${ }^{28}$

$$
y_{i t}=a_{i}+\sum_{k=1}^{K} \beta^{\mathrm{k}} * \mathrm{x}_{\mathrm{it}}^{\mathrm{k}}+\varepsilon_{\mathrm{it}},
$$

where $y_{i t}$ denotes GI (in log), $x_{i t}^{k}$ signifies the covariates described in the previous section, and $\mathrm{a}_{\mathrm{i}}$ represents country-specific fixed effects.

We tested the significance of a large set of covariates (described in Appendix Table 1): GDP growth; GDP in level or per capita; population size; fuel prices (international crude oil, coal, and domestic gasoline prices); cost variables (wages, unit labor costs, profit tax, cost of starting a business); inflation; variables measuring the availability and cost of financing (nominal, real, short- and long-term interest rates, domestic credit provided by banks, bank capital ratio, and business profit); energy dependency; carbon emissions per capita; R\&D spending; four policy support variables (FIT, RPS, biofuel mandates, and carbon pricing); human capital variables (spending on, and enrollment in, tertiary education); and the importance of green parties in politics.

Our preferred specification, which is both robust and parsimonious (a necessity, given the small sample size), includes five statistically significant variables which are: (i) GDP in constant dollars, (ii) the long-term real interest rate, (iii) the relative price of international crude oil ${ }^{29}$ (iv) the FIT dummy, and (v) the carbon pricing mechanism variable. Variables are in logarithm form (except the dummies and the real interest rate). Some enter the equation with one or two lags to allow sufficient time for GI to respond to its determinants (Table 4, column 1). The signs of the estimated coefficients are consistent with priors:

- $\quad$ Our results support the hypothesis that higher levels of income tend to boost investment in green technologies (column 1). Based on the estimated elasticity, an additional 1 percentage point of real GDP growth should raise real GI growth by

\footnotetext{
${ }^{27}$ Series in current dollars are converted into constant 2000 dollars to correct for domestic inflation and exchange rate movements.

${ }^{28}$ We use a fixed-effects estimator, although some of our variables are non-stationary. Kao (1999) and Phillips and Moon (2000) show that this estimator is consistent in non-stationary panels, even in the absence of co-integration. In support of this prediction, we find that the estimated coefficients of the covariates do not change significantly when the equation is estimated in levels or in ratios (see text).

${ }^{29}$ The relative price is computed as the ratio of the international crude oil expressed in domestic currency to the domestic GDP deflator.
} 
about 4 percentage points in the long-run, other factors being equal. This result remains valid if we use in the equation GDP per capita or the OECD constant PPP GDP per capita, instead of GDP (columns 2 and 3). In contrast, GDP growth, technological progress variables (R\&D and tertiary education), and population are not found to be significant. The fact that the population variable has no explanatory power could be an indication that non-market energy consumption is negligible in our sample of advanced and emerging economies, and that the GDP variable captures energy needs well.

- The cost of capital - proxied by the long-term real interest rate - has a significant and negative impact on GI with a lag (column 1). The estimated elasticity is quite large: GI declines by about 10 percent when the real interest rate increases by 1 percentage point. In contrast to the empirical literature on business investment, which finds that investment is relatively insensitive to real interest rates (Taylor 1999), GI seems to be very responsive to interest rate movements. This result, which is well documented in descriptive studies (BNEF 2011b), is not surprising given that renewable projects are capital intensive and rely mostly on external financing. The long-term nominal interest rate is also found significant (column 4). In contrast, short-term real interest rates are not significant, consistent with the notion that investment decisions in this area usually rely on multi-year financing plans. The importance of financing constraints is confirmed by the significance of two other variables: (i) the soundness of the banking sector, proxied by the bank capital-to-asset ratio, exerts a positive effect on GI (column 5); and (ii) profit also impacts GI, suggesting that reinvesting profits is an alternative to borrowing when market access is constrained (column 6). The second variable is nonetheless less robust to specification changes. Apart from the interest rate, other cost variables (wages, taxes, cost of starting a business) were found to be insignificant.

- $\quad$ Crude oil prices have a positive and large impact on GI with a lag (column 1): higher relative fuel prices increase the return to GI by raising the relative cost of electricity production based on fossil fuel combustion. Based on the coefficient estimate, GI grows by an additional percentage point when there is a 1 percentage point differential between increases in crude oil prices and economy-wide inflation (as proxied by the GDP deflator). In an alternative specification, coal (instead of crude oil) is also significant, but with a weaker and less robust impact on GI (column 7). ${ }^{30}$ In order to take into account country-specific energy pricing policies, we also run a

\footnotetext{
${ }^{30}$ Despite the predominant use of coal in electricity generation, our preferred specification includes crude oil, to better capture the substitution effect between gasoline and biofuels, and also because crude oil is a reference price in fossil fuel markets (for example, natural gas prices are often indexed to oil prices). In addition, international trade is less important for coal than crude oil, so that our coal reference price - the Australian thermal coal price - is an imperfect proxy for domestic coal prices in some countries (for instance in the United States).
} 
model with domestic gasoline prices, which are significant, but also sensitive to specification changes (results not reported). In addition, we find that the growth rate of crude oil prices has a positive effect on GI (column 8); one interpretation would be that green investors anticipate higher oil prices in the future when their growth rates are high. However, we do not find evidence that energy dependence encourages countries to invest in green technologies; on the contrary, the two variables are negatively related (column 9). We could not find any direct impact of carbon emissions on GI, probably because this effect is already captured by the carbon pricing variable.

- $\quad$ Finally, we tested the impact of the four policy support variables. Renewable portfolio standards and biofuel mandates do not seem to affect GI in our sample. In contrast, the FIT variable has a statistically significant effect with a lag (column 1). This result supports the view that FITs are one of the most important instruments supporting the expansion of renewables. Given that the FIT variable is a dummy, the estimate means that GI (in log and in real terms) is higher by about 1 point in countries with FITs. GI should therefore be two to three times larger in countries adopting FITs, other factors being equal. The effect of carbon pricing schemes is also significant in almost all specifications, with GI being higher by about 0.5 point in countries with either carbon tax or cap-and-trade, and by 1 point in countries with both schemes. This indicates that GI should be about 60 percent larger in the first case, and two to three times larger in the second case. The effect of green parties is insignificant in most specifications.

As indicated above, our results are robust to several alternative specifications. The sign, magnitude, and significance level of the aforementioned variables remain broadly unchanged when the model includes additional variables. Results are also robust if (i) we change the start and end dates of the sample, (ii) emerging countries are excluded from the sample, (iii) the model is estimated in nominal terms, or (iv) the explained variable is the GI-to-GDP ratio, rather than GI (column 10). We also re-estimated the model with de-trended variables to ensure that previous results are not distorted by the omission of a deterministic trend; the estimated coefficients are not fundamentally affected, although the R2 is smaller. The fall in GI during the financial crisis seems to be consistent with fundamentals, as the 2009 time dummy is not significant. The Hausman test of random versus fixed effects also suggests that the fixed effect model is the preferred specification. Finally, we do not correct for a possible endogeneity of GDP, as the reverse causality from investment to GDP is expected to be weak, given the relatively small size of the renewable sector. 
Table 4. Green Investment Determinants

\begin{tabular}{|c|c|c|c|c|c|c|c|c|c|c|}
\hline & \multirow{2}{*}{$\begin{array}{c}\text { Baseline } \\
(1)\end{array}$} & \multicolumn{9}{|c|}{ Alternative Specifications and Robustness Checks } \\
\hline & & $(2)$ & (3) & (4) & $(5)$ & (6) & $(7)$ & (8) & (9) & $(10)$ \\
\hline Dependent Variable: $\log (\mathrm{GI}){ }^{1}$ & level & level & level & level & level & level & level & level & level & ratio \\
\hline $\log (G D P)$ & $\begin{array}{l}3.59^{* *} \\
(1.99)\end{array}$ & & & $\begin{array}{c}3.42^{\star * *} \\
(1.86)\end{array}$ & $\begin{array}{l}4.16^{\star \star} \\
(2.22)\end{array}$ & $\begin{array}{c}3.91 \\
(1.58)\end{array}$ & $\begin{array}{c}7.06^{\star} \\
(4.95)\end{array}$ & $\begin{array}{c}3.37^{\star \star *} \\
(1.78)\end{array}$ & $\begin{array}{c}0.78 \\
(0.36)\end{array}$ & $\begin{array}{c}2.59 \\
(1.44)\end{array}$ \\
\hline LT Real Interest Rate $\{1\}$ & $\begin{array}{l}-0.12^{\star} \\
(-2.79)\end{array}$ & $\begin{array}{l}-0.12^{*} \\
(-2.76)\end{array}$ & $\begin{array}{l}-0.13^{*} \\
(-2.97)\end{array}$ & & $\begin{array}{l}-0.15^{*} \\
(-2.90)\end{array}$ & & $\begin{array}{l}-0.11^{\text {** }} \\
(-2.59)\end{array}$ & $\begin{array}{c}-0.10^{\star *} \\
(-2.23)\end{array}$ & $\begin{array}{l}-0.19^{*} \\
(-4.04)\end{array}$ & $\begin{array}{l}-0.12^{*} \\
(-2.79)\end{array}$ \\
\hline Log (relative crude oil price) $\{1\}$ & $\begin{array}{l}0.84^{* *} \\
(2.19)\end{array}$ & $\begin{array}{l}0.94^{* *} \\
(2.58)\end{array}$ & $\begin{array}{l}0.92^{* *} \\
(2.50)\end{array}$ & $\begin{array}{l}0.99^{\star *} \\
(2.50)\end{array}$ & $\begin{array}{c}0.65 \\
(1.58)\end{array}$ & $\begin{array}{l}1.19^{* *} \\
(2.49)\end{array}$ & & & $\begin{array}{l}0.97^{\star *} \\
(2.38)\end{array}$ & $\begin{array}{l}0.84^{\text {** }} \\
(2.19)\end{array}$ \\
\hline $\mathrm{FIT}\{2\}$ & $\begin{array}{c}1.16^{*} \\
(3.78)\end{array}$ & $\begin{array}{c}1.23^{*} \\
(4.03)\end{array}$ & $\begin{array}{c}1.18^{*} \\
(3.71)\end{array}$ & $\begin{array}{c}1.01^{*} \\
(3.31)\end{array}$ & $\begin{array}{c}1.06^{*} \\
(3.27)\end{array}$ & $\begin{array}{l}0.99^{* *} \\
(2.39)\end{array}$ & $\begin{array}{c}1.32^{*} \\
(4.46)\end{array}$ & $\begin{array}{c}1.21^{*} \\
(4.00)\end{array}$ & $\begin{array}{l}0.89^{\star *} \\
(2.53)\end{array}$ & $\begin{array}{c}1.16^{*} \\
(3.78)\end{array}$ \\
\hline Carbon Pricing Scheme & $\begin{array}{c}0.45^{\star \star \star} \\
(1.94)\end{array}$ & $\begin{array}{l}0.47^{\star *} \\
(2.04)\end{array}$ & $\begin{array}{l}0.52^{\star \star} \\
(2.20)\end{array}$ & $\begin{array}{c}0.42^{\star \star *} \\
(1.74)\end{array}$ & $\begin{array}{l}0.63^{\star \star} \\
(2.48)\end{array}$ & $\begin{array}{l}0.74^{* *} \\
(1.98)\end{array}$ & & $\begin{array}{c}0.27 \\
(1.11)\end{array}$ & $\begin{array}{l}0.54^{* *} \\
(2.03)\end{array}$ & $\begin{array}{c}0.45^{\star \star \star} \\
(1.94)\end{array}$ \\
\hline Log (GDP per capita) & & $\begin{array}{c}3.79^{\star \star \star} \\
(1.92)\end{array}$ & & & & & & & & \\
\hline Log (GDP per capita PPP) & & & $\begin{array}{l}3.78^{* *} \\
(2.04)\end{array}$ & & & & & & & \\
\hline Log (LT nominal interest rate) & & & & $\begin{array}{l}-1.72^{*} \\
(-3.48)\end{array}$ & & $\begin{array}{l}-2.36^{*} \\
(-3.42)\end{array}$ & & & & \\
\hline Capital Ratio & & & & & $\begin{array}{c}0.10^{\star * *} \\
(1.91)\end{array}$ & & & & & \\
\hline $\log ($ profit $)\{1\}$ & & & & & & $\begin{array}{l}0.39^{\star *} \\
(2.12)\end{array}$ & & & & \\
\hline Log (relative coal price) $\{1\}$ & & & & & & & $\begin{array}{l}0.50^{\star *} \\
(1.98)\end{array}$ & & & \\
\hline Log (relative crude oil price) & & & & & & & & $\begin{array}{l}1.07^{\star *} \\
(2.33)\end{array}$ & & \\
\hline Dlog (relative crude oil price) $\{1\}$ & & & & & & & & $\begin{array}{l}0.86^{\star \star} \\
(2.16)\end{array}$ & & \\
\hline Log (energy dependence) & & & & & & & & & $\begin{array}{l}-0.86^{*} \\
(-2.68)\end{array}$ & \\
\hline R2 & 0.67 & 0.67 & 0.68 & 0.68 & 0.69 & 0.71 & 0.71 & 0.68 & 0.71 & 0.58 \\
\hline OBS & 232 & 232 & 221 & 225 & 215 & 139 & 250 & 232 & 183 & 232 \\
\hline DF & 197 & 197 & 186 & 190 & 180 & 109 & 214 & 196 & 150 & 197 \\
\hline
\end{tabular}

Source: IMF staff estimates.

${ }^{1}$ Level: log (GI); ratio: log (GI/GDP).

Note: Annual data over 2000-2010; fixed-effects estimation; t-statistics in parentheses; ${ }^{* * *}\left({ }^{* *},{ }^{*}\right)=$ significant at the $1(5,10)$ percent level. 


\section{Conclusion And Policy Implications}

Our study contributes to the economic literature on GI in three main ways. First, we propose a measurable definition of GI. Second, we analyze the trends in GI and underline important changes in country leadership in the GI sector. Third, we conduct the first econometric assessment of the macroeconomic drivers of GI, which yields important insights for policy design.

Our results suggest that renewable GI has become a global phenomenon. At the same time, the regional composition of GI has changed dramatically in recent years. Asia, led by China, is increasingly important. China became the country with the highest investment in renewables in 2009, and has invested more in renewable energy than Europe as a whole in 2010. This shift in leadership reflected, to a large extent, differences in macroeconomic performance.

Our results imply that GI can be powerfully influenced by public policies. While macroeconomic factors such as economic growth, interest rates, and profit developments matter, so too do energy policies. GI increases when its cost, relative to traditional fossil fuel technologies, is reduced by higher oil prices. This implies that higher taxation of fossil fuels to address negative externalities associated with their use, or a reduction in subsidies, would help foster green investment. ${ }^{31}$ The boost to GI from higher energy prices could be quite large: a 10 percent increase in fuel prices - assuming other prices in the economy were to remain constant — could lead to a 10 percent increase in GI.

Specific public interventions to support GI can also be useful. The econometric results suggest that feed-in-tariffs and carbon pricing mechanisms tend to support GI. FIT stands out as one of the most important instruments for supporting the expansion of renewable energy, with GI being two to three times larger when countries adopt such a scheme (other factors being equal). Many policies, however, do not seem to be effective, including support for biofuels. This adds further to concerns regarding the effectiveness of biofuel subsidies and their adverse effects on food supply (IMF 2008c and 2008d, Jones and Keen 2009).

\footnotetext{
${ }^{31}$ See Coady and others (2010) for an overview of developments in fuel subsidies.
} 


\section{Appendix 1. Green Investment in Economic and Business Publications}

GI in this study differs from other concepts used in the climate change and environmental literature:

- $\quad$ Few insights into GI can be gained from macroeconomic studies. The macroeconomic approach to climate change has focused on the output or consumption costs of reducing GHG emissions. These studies are intended to inform the setting of objectives and the choice and design of delivery mechanisms, such as carbon taxes, or permit trading schemes. IMF (2008a), for example, explicitly models the impact of a carbon tax on total investment, but capital is not differentiated by type (e.g., "green" or "brown").

- A vast forward-looking literature estimates mitigation and adaptation costs to climate change and needed investments. Most studies compare two scenarios by 2030: a business-as-usual (or reference) scenario, in which emissions and temperature increase sharply, and a normative scenario designed to meet a certain climate target (IEA 2010). Reports measure incremental investment needs compared to the business-as-usual scenario. ${ }^{32}$ Generally, the needed investment is computed using climate models (see World Bank 2009 for a model review).

- $\quad$ The term GI is also commonly used by development banks, but this is not directly relevant to our study. Countries with commitments under the Kyoto Protocol face several options to reduce greenhouse gas emissions. One is to acquire emission reduction credits from other countries through a procedure called "emission trading." A Green Investment Scheme (GIS) is one type of contract within the framework of the international emission trade market. Most economies in transition do not exhaust their Kyoto quotas and have carbon emission credits to sell to countries that exceed their quotas. Under the GIS, the proceeds from the sale of surplus assigned emission amounts by transition economies are "greened," which means they are reinvested locally in mitigation projects. GIS's are not yet precisely defined or requested by the Kyoto Protocol, but countries can sign such agreements on a voluntary basis. Some development banks are actively involved in the development of GIS's (see Tuerk and others 2010).

\footnotetext{
${ }^{32}$ This investment need is not a measure of GI: First, the reference scenario also incorporates mitigation measures. Second, incremental investment results from the combination of higher green investment and lower "dirty" investment (for instance, investment in fossil fuel supply is significantly scaled down in the IEA 450 scenario).
} 


\section{Appendix 2. The New Energy and Finance Database}

The BNEF database is the most comprehensive source of information on finance in the renewable energy sector available. It covers 32,500 organizations, 21,500 projects, and 17,000 transactions. The database also records information on the type, location, and timing of investments in green technologies such as biomass, geothermal, wind (more than 1MW), solar (more than 0.3MW), biofuel, marine, and small scale hydro (between 0.5 and 50MW). BNEF only includes the investment figure when a project/business is completed or becomes operational. BNEF does not report investment on large hydro and nuclear projects. Public investment is also largely not recorded.

BNEF provides limited data on energy efficiency investments (for instance, investment in energy smart technologies). However, these are highly incomplete and exclude some mainstream investments (for example, energy efficiency technologies in buildings and industrial equipment are not included).

BNEF has separate investment data on corporate and government R\&D and small projects (such as micro wind turbine, solar rooftop and solar water heaters). This data is not included in the general trend discussion in Section IV.A, and is addressed separately in Appendix 5.

\section{Appendix 3. Energy, Electricity, Power, and Capacity}

Energy is the capacity of a physical system to perform work. Energy exists in several forms including heat, kinetic or mechanical energy, light, and electricity. The standard unit of energy is the joule $(\mathrm{J})$. But other units exist, such as the British thermal unit (Btu), the Kilowatt hour (kWh), or the tone of oil equivalent (toe), which are all multiples of joules.

Although the terms "energy" and "power" are synonyms in everyday usage, scientists distinguish between them. Power is the rate at which energy is generated. For instance, a hydroelectric plant converts water's potential energy into kinetic energy and, ultimately, into electric energy, whereas the amount of electric energy that is generated per unit of time is the electric power. Power has the unit "watt," which is equal to one joule per second.

The economic literature uses the term electrical "capacity" to refer to the power of an electric plant (in watts), whereas electricity "generation" refers to the energy produced by the plant (in watt hour). 


\section{Appendix 4. Key Renewable Technologies: Definition and Trends ${ }^{33}$}

Renewable GI (excluding large hydro projects) is dominated by wind power. However, solar, biomass, and biofuels are also fast-growing technologies (Appendix Figure 1). Together, these four technologies accounted for over 90 percent of total renewable GI in 2010.

\section{Box 1. Selected Renewable Technologies: Terminology and Key Features}

Biofuels: A wide range of fuels derived from biomass (either from organic living organisms or from metabolic byproducts) and used for transport.

Biomass: Energy produced from organic material grown, collected, or harvested for energy use. Feedstock absorbs carbon while growing, and returns it when burned or decaying, with zero net increase in carbon. Biomass is the only renewable energy that can be used for all three of the major categories of energy consumption, namely, electrical power generation, heat production, and transport fuels.

Geothermal: Heat extracted from the earth, usually in the form of hot water or steam. It can be exploited for electricity generation or for direct use in district heating systems.

Hydropower: Results from the conversion of the kinetic energy of water into electricity, produced either in run-of-river plants or reservoirs. It is the most mature renewable energy technology.

Solar: There are three types of technology available:

- Solar photovoltaic (PV) converts direct and diffused solar radiation into electricity through solar panels.

- Concentrated solar power (CSP) uses lenses or mirrors to concentrate sunlight to produce a high heat and then converts it into electricity. CSP can only exploit direct sunlight.

- Solar Thermal (ST) produces heat derived from solar radiation by heating a fluid circulated through a collector. ST can exploit both direct and diffused sunlight.

Wind: Exploits the kinetic energy of wind for electricity generation through the use of turbines.

Sources: IEA 2010 WEO; Renewable Energy Policy Network 2010; and IMF staff.

\footnotetext{
${ }^{33}$ This appendix is based on data from the BNEF database. Investment data on GI components is less reliable (and insignificant) before 2004 in this database.
} 
Wind power is the most commercially viable renewable technology. It represented on average about half of total renewable GI over 2004-2010. Compared to other renewable technologies, wind investment has experienced steadier growth due to technology maturity, lower risk, policy support (especially under the form of FITs), and cheaper capital costs. Wind also proved more robust in the face of the economic slowdown, sustaining growth rates of 22 percent and 14 percent in 2008 and 2009, respectively. Most investment in renewable energy now goes into wind power. Recent increases are almost exclusively due to a boom in wind projects in China, which toppled the United States and became the largest investor in this technology in 2009 (although installed capacity is still larger in the U.S.).

To date, solar is the second-most invested technology after wind. Investment in solar power increased elevenfold between 2005 and 2008, but suffered a significant correction in 2009 (by 24 percent) and stagnated in 2010. The decline was due to several factors. These included a shortage of financing, with solar being perceived as a less mature and higher-risk technology; a sharp drop in solar equipment prices as the whole industry shifted suddenly from excess demand to excess supply; and less favorable public support in Spain, one of the most important markets.

\section{Appendix Figure 1. Renewable Green Investment by Technology, 2004-2010}

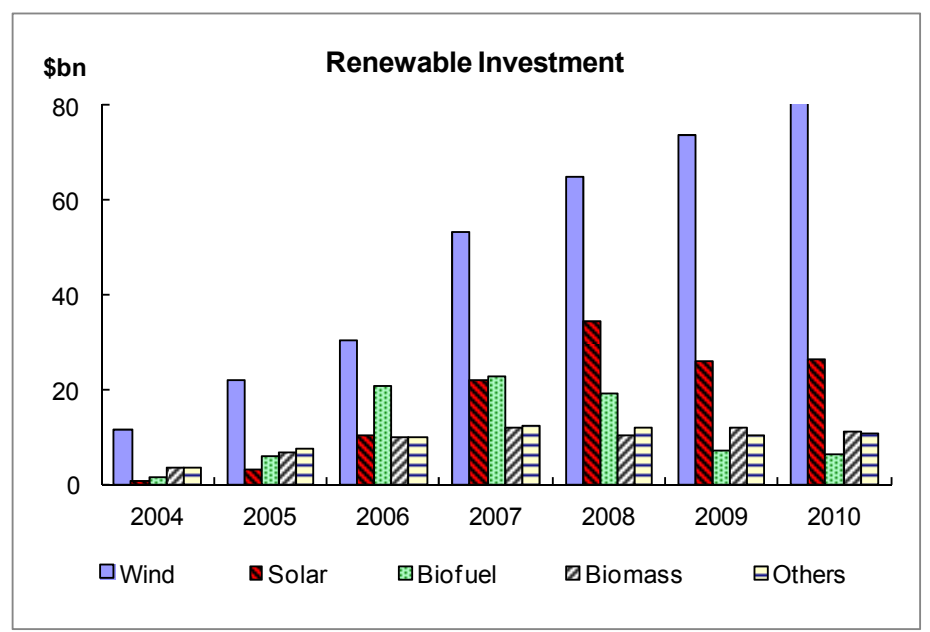

Source: BNEF.

Biomass, the second-largest technology in the early 2000s, lost its leading role owing to less supportive public policies and feedstock-related bottlenecks (long-term availability and price security cannot be guaranteed by suppliers, and prices lack transparency, as biomass is mostly bilaterally traded). Nonetheless, it showed some resilience in 2009, which could reflect the perception by investors that this is a more mature technology (BNEF 2010d). Investment in biofuels boomed in 2005 and 2006, having been supported by aggressive 
policies,${ }^{34}$ but has since stalled due to high feedstock prices and over-capacity, particularly in the United States. In 2009, the biofuel industry was severely affected by the fall in oil prices and lower overall demand for oil that limited the amount of biofuels that could be absorbed by gasoline and diesel blending pools. Investment was also deterred by higher crop and output prices, concerns about the environmental sustainability of production, as well as the impact on overall greenhouse gas emissions and food prices (IEA 2009). ${ }^{35}$

\section{Appendix 5. Research and Development in Green Technologies}

R\&D in green technologies is an important component of GI. R\&D can also be measured using the BNEF database, although it does not cover R\&D in large hydro and nuclear powers.

R\&D in renewable energies has steadily increased since $2004^{36}$ and was broadly constant in nominal terms in 2009 despite the crisis (Appendix Figure 2). That year, the increase in public $R \& D$, as supported by stimulus plans, more than offset lower private spending. BNEF (2010d) estimates that, on average, 14 percent of the green stimulus was allocated R\&D.

Europe and the United States are the largest investors in renewable R\&D, respectively, with $\$ 12$ billion and $\$ 7$ billion in 2009. Private sector R\&D accounted for the majority of European spending ( $\$ 8$ billion out of $\$ 12$ billion), whereas R\&D was more equally distributed in the U.S. (\$4 billion for public R\&D out of $\$ 7$ billion).

\section{Appendix Figure 2. Public and Private R\&D in the World}

(Billions of dollars)

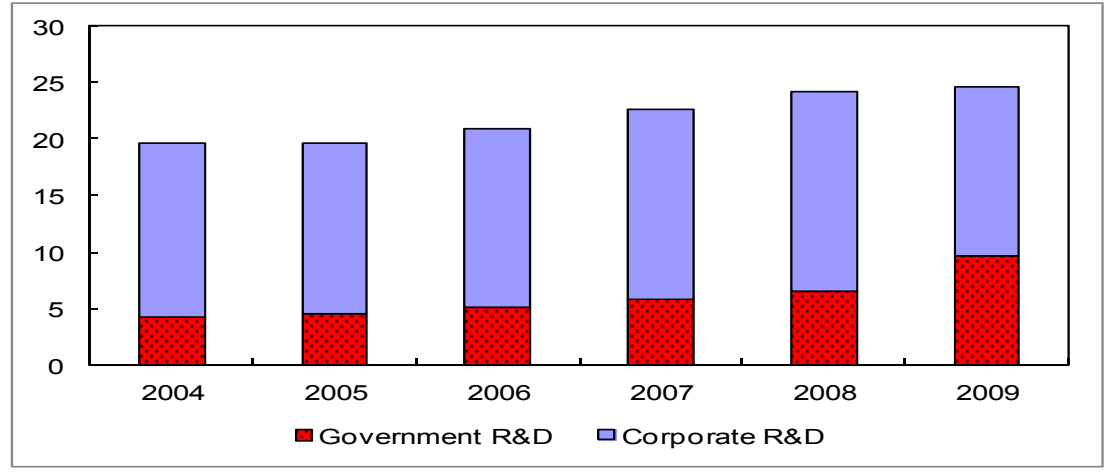

Source: BNEF.

\footnotetext{
${ }^{34}$ According to Global Subsidies Initiative (2010b), EU governments provided around $\$ 5$ billion in public support in 2006, principally in the form of excise tax credits, while direct support to the industry in the United States amounted to $\$ 8-\$ 10$ billion.

${ }^{35}$ Large increases in biofuel production in the United States and Europe could be a driving factor behind the steep rise in global food prices, as corn is a food as well as a fuel (on the food vs. fuel controversy, see Mitchell 2008, IEA, 2008, and IMF, 2008a).

${ }^{36} \mathrm{BNEF}$ provides data on R\&D starting in 2004.
} 
In terms of technology, R\&D mainly focuses on improving the energy efficiency of existing processes rather than bringing new technologies into the market. In 2008, 70 percent of total R\&D was allocated to energy-smart technologies. ${ }^{37}$

Amounts allocated to $R \& D$ on renewables remain small compared to nuclear power. In the sample of IEA countries, public R\&D on renewable energy — although comparable in size with fossil fuel R\&D - accounted for only one-third of the financing given to nuclear power in recent years (IEA, OPEC, OECD, and WB joint report 2010). This seems surprising, given that many renewable technologies are still in early stages of development and need significant research funding. The fact that R\&D spending is relatively small and concentrated on energy efficiency may be a source of concern for the further deployment of new technologies (IEA 2008).

\section{Appendix 6. Country List and Data Sources}

The 35 countries covered in the econometric analysis are Australia, Austria, Belgium, Brazil, Canada, Chile, China, Czech Republic, Denmark, Finland, France, Germany, Greece, Hungary, Iceland, India, Ireland, Italy, Japan, Korea (Republic), Luxemburg, Mexico, the Netherlands, New Zealand, Norway, Poland, Portugal, Slovak Republic, Slovenia, Spain, Sweden, Switzerland, Turkey, the United Kingdom, and the United States.

\footnotetext{
${ }^{37}$ These technologies include, for instance, efficient lighting and insulation, smart grids, new batteries, and hybrid or electric vehicles.
} 


\section{Appendix Table 1. List of Variables, Definitions, and Sources}

\begin{tabular}{|c|c|c|}
\hline Variable & Definition & Source \\
\hline Renewable investment & $\begin{array}{l}\text { Financial investment in renewables, excluding large hydro projects, in } \\
\text { billions of dollars }\end{array}$ & BNEF \\
\hline GDP & $\begin{array}{l}\text { Nominal and real GDP in dollars and domestic currency } \\
\text { (in billions) }\end{array}$ & WEO \\
\hline $\begin{array}{l}\text { GDP per capita PPP, } \\
\text { constant }\end{array}$ & In billions of dollars & OECD \\
\hline Population & In millions & WEO \\
\hline Inflation & GDP deflator & WEO \\
\hline International gasoline price & In dollars per liter & Reuters \\
\hline Crude oil price & $\begin{array}{l}\text { Simple average of three spot prices: Dated Brent, West Texas } \\
\text { Intermediate, and the Dubai Fateh, US\$ per barrel }\end{array}$ & WEO \\
\hline Domestic gasoline price & In dollars per liter & IMF FAD \\
\hline Wage & $\begin{array}{l}\text { Compensation of employees, in billions of dollars } \\
\text { (National Accounts) }\end{array}$ & $\begin{array}{l}\text { OECD, Economic } \\
\text { Outlook }\end{array}$ \\
\hline Unit labor cost & Total economy, 2005 base & $\begin{array}{l}\text { OECD, Economic } \\
\text { Outlook }\end{array}$ \\
\hline Profit & $\begin{array}{l}\text { Gross operating surplus and mixed income, in millions of dollars (National } \\
\text { accounts) }\end{array}$ & $\begin{array}{l}\text { OECD, Economic } \\
\text { Outlook }\end{array}$ \\
\hline Cost of starting a business & Percent of per capita income & $\begin{array}{l}\text { Doing Business } \\
\text { indicators, WDI }\end{array}$ \\
\hline Interest rates & Nominal and real, short-term and long-term & WEO \\
\hline Tax on business & Tax paid by businesses in percent of profit & $\begin{array}{l}\text { Doing Business } \\
\text { indicators, WDI }\end{array}$ \\
\hline Fossil fuel use & Fossil fuel energy use, percent total energy use & WDI \\
\hline Green parties & Share of votes and share of seats & $\begin{array}{l}\text { Comparative political } \\
\text { dataset }\end{array}$ \\
\hline Domestic credit & Domestic credit to the private sector (percent of GDP) & IMF IFS \\
\hline Bank capital & Bank capital-to-asset ratio & IMF GFS report \\
\hline Energy dependency & Net energy imports, percent of energy use & WDI \\
\hline Carbon emissions & Per capita metric tons & WDI \\
\hline $\mathrm{R} \& \mathrm{D}$ & Expenditure for R\&D, percent of GDP & WDI \\
\hline FIT & Dummy $(0=$ no FIT $)$ & IMF Staff \\
\hline RPS & Dummy (0=no RPS) & IMF Staff \\
\hline Biofuel mandates & Dummy ( $0=$ no mandate $)$ & IMF Staff \\
\hline Carbon pricing schemes & $\begin{array}{l}\text { Categorical viable }(0=\text { neither carbon tax nor cap-and-trade; } 1=\text { either; } \\
2=\text { both })\end{array}$ & IMF Staff \\
\hline $\begin{array}{l}\text { Spending on tertiary } \\
\text { education }\end{array}$ & Public expenditure per student, percent of GDP per capita & UNESCO, WDI \\
\hline $\begin{array}{l}\text { Enrollment in tertiary } \\
\text { education }\end{array}$ & Gross enrollment in percent of relevant age group & UNESCO, WDI \\
\hline Coal price & Australian coal; 2005-based index (US\$ per Mt) & WEO \\
\hline
\end{tabular}

Source: IMF staff. 


\section{References}

Accenture, 2011, New Waves of Growth: Unlocking Opportunity in the Multi-Polar World (Oxford: Worldwide).

Ambec, S., and P. Lanoie, 2007, "When and Why Does it Pay to Be Green?" GAEL Working Paper 2007-05 (Quebec: CIRANO).

Attanasio, O.P., L. Picci, and A. Scorcu, 2000, "Saving, Growth, and Investment: A Macroeconomic Analysis Using a Panel of Countries," The Review of Economics and Statistics, Vol. 82, No. 2, pp. 182-211.

Baldacci and others, 2008, "Social Spending, Human Capital, and Growth in Developing Countries," World Development, Vol. 36 (Washington: International Monetary Fund).

Blanchard, O., 2008, Macroeconomics (New Jersey: Prentice Hall).

Bloomberg New Energy Finance (BNEF), 2010a, Clean Energy-Analyst Reaction, February 12, 2010 (London: New Energy Finance).

—_, 2010b, Clean Energy_Analyst Reaction, June 24, 2010 (London: New Energy Finance).

— $2010 \mathrm{c}$, Green Investing 2010 (London: New Energy Finance).

— Finance).

—, 2011a, Clean Energy-Analyst Reaction, February 18, 2011 (London: New Energy Finance).

— , 2011b, Green Investing 2011 (London: New Energy Finance).

Brunnermeier, S. B., and M. A. Cohen, 2003, "Determinants of Environmental Innovation in U.S. Manufacturing Industries,” Unpublished.

Coady and others, 2010, "Petroleum Product Subsidies: Costly, Inequitable, and Rising," IMF Staff Position Note 10/05 (Washington: International Monetary Fund).

Cropper M., and C. Griffiths, 1994, "The Interaction of Population Growth and Environmental Quality," American Economic Review, Vol. 84, No. 2, pp. 250-4. 
Environmental Law Institute, 2009, Estimating U.S. Government Subsidies to Energy Sources: 2002-2008 (Washington).

Eurostat, 2009, The Environmental Goods and Services Sector (EGSS Handbook), Eurostat European Commission (Luxembourg).

Global Subsidies Initiative, 2010a, Relative Subsidies to Energy Sources: GSI Estimates (Geneva).

Global Subsidies Initiative, 2010b, Biofuel-At What Cost, Government Support for Ethanol and Biodiesel in the European Union-2010 Update (Geneva).

Grossman, G. M., and A.B. Krueger, 1994, "Economic Growth and the Environment," NBER Working Paper No. 4634 (Washington: International Monetary Fund).

Guerrieri, P., M. Luciani, and V. Meliciani, 2010, “The Determinants of Investment in Information and Communication Technologies," Economics of Innovation and New Technologies, Vol. 20, pp. 387-403.

International Energy Agency (IEA), 2008, World Energy Outlook 2008 (Paris).

—., 2009, World Energy Outlook 2009 (Paris).

— , 2010, World Energy Outlook 2010 (Paris).

—, OECD, OPEC, WB, 2010, Analysis of the Scope of Energy Subsidies and Suggestions for the G20 Initiative, Joint Report (Toronto).

Intergovernmental Panel on Climate Change (IPCC), 2007, Fourth Assessment Report (AR4) (Switzerland).

International Monetary Fund, 2008a, Climate Change and the Global Economy, World Economic Outlook (Washington).

—, $2008 \mathrm{~b}$, The Fiscal Implications of Climate Change, Board Paper SM/08/59 (Washington).

- 2008c, Food and Fuel Prices-Recent Developments, Macroeconomic Impact, and Policy Responses, Board Paper SM/08/307 (Washington).

—, 2008d, Fuel and Food Price Subsidies - Issues and Reform Options, Board Paper SM/08/299 (Washington). 
—, 2010, Fiscal Monitor, October 2010 (Washington).

Johnson, D., and K. Lybecker, 2009, "Challenges to Technology Transfer: A Literature Review of the Constraints on Environmental Technology Dissemination," Colorado College Working Paper (Colorado Springs).

Jones, B., and M. Keen, 2009, "Climate Policy and the Recovery,” IMF Staff Position Note SPN/09/28 (Washington: International Monetary Fund).

Kao, Chihwa, 1999, "Spurious Regression and Residual-Based Tests for Cointegration in Panel Data," Journal of Econometrics, Vol. 90, pp. 1-44.

Krupnick A. J. and others, 2010, “Toward a New National Energy Policy: Assessing the Options" (Washington: The National Energy Policy Institute, Resources for the Future).

Lamont, O., 1997, "Cash Flow and Investment: Evidence from Internal Capital Markets," Journal of Finance, Vol. 52, No. 1, pp. 83-109.

Martin, R., M. Muûls, and U. Wagner, 2011, Climate Change, Investment and Carbon Markets and Prices-Evidence from Manager Interviews (San Francisco: Climate Policy Initiative).

McKinsey \& Company, 2009, Pathways to a Low-Carbon Economy (New York).

Mitchell, D., 2008, “A Note on Rising Food Prices,” World Bank Policy Research Working Paper No. 4682 (Washington: World Bank).

Morriss, A. P. and others, 2009, “7 Myths About Green Jobs,” Law \& Economics Research Paper No. LE09-001, PERC Policy Series, No. 44 (Illinois: University of Illinois).

Newell, R. G., A. B. Jaffee, and R. N. Stavins, 1999, "The Induced Innovation Hypothesis and Energy-Saving Technological Change," Quarterly Journal of Economics (1999), Vol. 114, No. 3, pp. 941-75.

Organization of Economic Cooperation and Development (OECD), 2011, Towards Green Growth (Paris).

Parry, I., 2011, "Reforming the Tax System to Promote Environmental Objectives: An Application to Mauritius," IMF Working Paper WP/11/124 (Washington: International Monetary Fund). 
Phillips, P., and H. Moon, 2000, "Nonstationary Panel Data Analysis: An Overview of Some Recent Developments," Econometric Reviews, Vol. 19.

Pollin, R., 2009, "Response to 'Seven Myths about Green Jobs,' and 'Green Jobs Myths,'” Political Economy Research Institute, Working Paper 198 (Amherst: University of Massachusetts).

Popp, D., 2002, “Induced Innovation and Energy Prices," American Economic Review, Vol. 92, pp. $160-80$.

PriceWaterhouseCoopers, 2008, Going Green: Sustainable Growth Strategies (New York).

Renewable Energy Policy Network for the 21st Century (REN21), 2010, Renewables 2010Global Status Report (Worldwide).

Schlissel, D., and B. Biewald, 2008, Nuclear Power Plant Construction Costs (Cambridge, MA: Synapse Energy Economics, Inc.).

Stern, D. I., 2004, “The Rise and Fall of the Environmental Kuznets Curve,” World Development, Vol. 32, No. 8, pp. 1419-39.

Taylor, M., 1999, "Real Interest Rates and Macroeconomic Activity," Oxford Review of Economic Policy, Vol. 15, No.2.

Tuerck, D., B. Powell, and P. Bachman, 2009, "Green Collar Job Creation: A Critical Analysis," The Beacon Hill Institute Policy Study, Vol. 3.

Selden, T., and D. Song, 1994, "Environmental Quality and Development: Is There a Kuznets Curve for Air Pollution Emissions?" Journal of Environmental Economics and Management, Vol. 27, pp. 147-62.

Stern, D. I., Common, S. M., and E. B. Barbier, 1996, "Economic Growth and Environmental Degradation: The Environmental Kuznets Curve and Sustainable Development," World Development, Vol. 24, No. 7, pp. 1151-60.

Sliglitz, J. E., 1998, "More Instruments and Broader Goals: Moving Toward the PostWashington Consensus," Speech (Helsinki: The World Bank Group).

Stokey, N. L., 1998, “Are There Limits to Growth?” International Economic Review, Vol. 39, No. 1, pp. 1-31. 
Tuerk, A. and others, 2010, Green Investment Schemes: First Experiences and Lessons Learned, Joanneum Research Center (Austria: Institute for Energy Research).

U.S.-China Economic and Security Review Commission, 2010 Report to Congress of the U.S. - China Economic and Economic and Security Review Commission (Washington).

U.S. Energy Information Administration, 2010, International Energy Outlook 2010 (Washington).

World Bank, 2009, World Development Report 2010: Development and Climate Change (Washington). 